\title{
強震観測記録に基づく相模トラフ沿いの地震の 長周期・長時間地震動の予測式 \\ LONG-PERIOD AND LONG-DURATION GROUND MOTION PREDICTION EQUATIONS FOR EARTHQUAKES ALONG THE SAGAMI TROUGH BASED ON STRONG MOTION RECORDS
}

\author{
佐藤智 美 ${ }^{* 1}$, 中川博 ${ }^{* 2}$, 小山 信*3, 佐藤 俊明*4, 藤 堂正 喜 ${ }^{* 5}$ \\ Toshimi SATOH, Hiroto NAKAGAWA, Shin KOYAMA, \\ Toshiaki SATO and Masanobu TOHDO
}

\begin{abstract}
We develop long-period and long-duration ground motion prediction equations for earthquakes along the Sagami Trough based on strong motion records. The site factors are estimated at the engineering bedrock by using shallow structure models developed by NIED. The obtained amplification factors are smaller than those for earthquakes along the Nankai Trough. The developed equations are applied to the 1923 Taisho Kanto type earthquake and the hypothesized south Tokyo metropolitan earthquake. The ground motions predicted for the 1923 Taisho Kanto type earthquake are consistent to a record observed at Hongo and ones predicted by 3D-FDM by HERP.
\end{abstract}

Keywords: Sagami Trough, Long-period and long-duration ground motions, Prediction equation, The 1923 Taisho Kanto earthquake, Tokyo metropolitan earthquake 相模卜ラフ，長周期・長時間地震動，予測式，1923 年大正関東地震，首都直下地震

\section{1. はじめに}

2003 年十勝沖地震 $\left(M_{J} 8.0\right)$ や 2011 年東北地方太平洋沖地震 (Mw9.0)では, 堆積層の厚い平野部を中心に, 広範囲で長周期・長時 間地震動が観測された。2011 年東北地方太平洋沖地震では, 関東地 域の鉄筋コンクリート系の超高層建築物が，本震時の初期状態から 1 次固有振動数が 2 4 割低下し, 記録終了まで初期状態に戻らずに 低下したままとなっていることが報告されている 1)。このような背 景を踏まえ, 筆者らは, 発生確率が高い2)南海トラフ沿いの地震の 長周期・長時間地震動の予測式を作成し ${ }^{3), 4}$, 超高層建築物の設計用 地震動策定に向けた検討 5)を行った。これに基づき，国土交通省 6 が,「超高層建築物等における南海トラフ沿いの巨大地震による長周 期地震動への対策について」を公表し, 2017 年 4 月以降に超高層建 築物等を新築する際の大臣認定の運用が強化されている。

しかし，この予測式は，相模トラフ沿いの地震は適用範囲外であ り 3)，他の研究でも同地震に適用できる長周期・長時間地震動の経 験的予測式はない。M 8 クラスの相模トラフ沿いの地震の 50 年以内 の発生確率はほぼ 0 〜 $10 \%$ r゙あるが, ひとたび発生すれば, 超高層
建築物が多数立地している 5 )関東地方で大きな長周期・長時間地震 動が生じることが懸念される。また, プレートの沈み込みに伴う M7 クラスの地震の 50 年以内の発生確率は $80 \%{ }^{22}$ と高い。そこで, 本研 究では, M8 クラスの相模トラフ沿いの地震とプレートの沈み込み に伴う M7 クラスの首都直下地震に対寸る超高層建築物の設計用地 震動策定を目指し，長周期・長時間地震動の予測式を作成した。そ して, 大正関東地震, 内閣府 7)が想定しているフィリピン海プレー トのスラブ内地震である都心南部直下地震への適用を行ない，大正 関東地震の復元波 8)や，既往の計算波 7),9) との比較を行った。

作成した予測式は，南海トラフ沿いの地震の長周期・長時間地震 動の予測式 3) と同様に，強震記録に基づくものであるが，減衰定数 $5 \%$ 加速度応答スペクトルの予測式に関しては, 主に以下の点で異 なっている。ひとつめは，南海トラフ沿いの地震の予測式では， $\mathrm{M}_{\mathrm{s}}$ $\geqq 6.5$ の海溝型地震を用いていたが，相模トラフ沿いの地震の予測 式では, それに加え, 想定震源域では $\mathrm{M}_{J} \geqq 4.0$ の地震も対象とした。 これは, 震源位置により長周期地震動の振幅や卓越周期が異なると いう知見を踏まえ，伝播経路特性，地盤増幅特性に相模卜ラフ沿い
*1 (株大崎総合研究所リサーチフェロー・博士 (工学)

*2 (国)建築研究所構造研究グループ 主任研究員・博士 (工学

*3 国土交通省国土技術政策総合研究所 建築新技術統括研究官・博士 (工学)

*4 (株)大崎総合研究所所長. 工博

*5 (株)大崎総合研究所 主席研究員・博士 (工学)
Research Fellow, Ohsaki Research Institute, Dr.Eng.

Senior Research Engineer, Dept. of Structural Eng., Building Research Institute, Dr.Eng.

Research Managing Coordinator for Advanced Building Technology, National Institute for Land and Infrastructure Management, Dr.Eng.

Director, Ohsaki Research Institute, Dr.Eng.

Principal Researcher, Ohsaki Research Institute, Dr.Eng. 
の地震の地域性を反映させるためである。これに伴い, 広い範囲の マグニチュードのスケーリングに対応するため, NGA-WEST2 の地 震動予測式で用いられているヒンジマグニチュード 10),11) 導入し た二段階回帰とした。2つめは, フィリピン海プレートの上端深さ は神奈川県西部で $10 \mathrm{~km}$ 以下 7) と浅いため, 震源近傍での地震動レ ベルの飽和の係数の推定に, 地凯内地震の強震記録も加えた。3つ めは, プレート境界地震とスラブ内地震の違いを考慮し, それぞれ に対して震源深さをパラメータとしたモデル化を行ったことである。 これにより, 地震タイプによる短周期レベルの違いや, 深さによる 表面波の励起特性の違いを反映できる。 4 つめは, 工学的基盤以浅 の 1 次元的地盤増幅をはぎとり, 工学的基盤で評価したことである。 長時間地震動を表現する群遅遅延時間の平均值・分散の予測式に関 しても，ほぼ同じ条件のデータを用いて、プレート境界地震とスラ ブ内地震を区別し, 工学的基盤で評価している。

\section{2. データと手法}

\section{(1) 予測式作成用データ}

予測式作成には, 1987 年 2016 年 4 月の全国の $\mathrm{M}_{\mathrm{J}} \geqq 6.5$ の海溝 型地震と, 相模卜ラフ沿いの地震の震源域の $\mathrm{M}_{\mathrm{J}} \geqq 4.0$ の海溝型地震 の強震記録を用いた。海溝型地震はプレート境界地震とスラブ内地 震であり, スラブ内地震は想定する首都直下地震の深さに鑑み, 震 源深さ $\mathrm{H} \leqq 75 \mathrm{~km}$ とした。震源に近い関東地方での予測を重要視し, 断層最短距離 $\mathrm{R}_{\mathrm{rup}}$ は $250 \mathrm{~km}$ 以下とした。後述する二段階回帰分析 の一段階目では, 全国の $\mathrm{M}_{J} \geqq 6.0, \quad \mathrm{R}_{\text {rup }} \leqq 200 \mathrm{~km}$ の地殼内地震と関 東地方の $\mathrm{M}_{\mathrm{J}} \geqq 4.0$ の地殼内地震の強震記録も用いた。強震観測記録 は, K-NET, KiK-net(地表と地中), 気象庁 87 型, 気象庁 95 型, 工学院大学の記録の他, 首都直下地震である 1987 年千葉県東方沖 地震 $\left(\mathrm{M}_{\mathrm{J}} 6.7\right)$ の記録 12)である。また, 福島・田中 13)の距離減衰式で $3 \mathrm{~cm} / \mathrm{s}^{2}$ 以上となる距離以内の記録という条件も付与した。プレート 境界地震は 55 個, スラブ内地震は 52 個, 地殼内地震は 53 個選択 されている。

Fig.1には, 震央位置(気象庁) ・ CMT 解(F-net, Global CMT)及び 観測点位置を示す。Fig. 2 には, $\mathrm{Mw}$ と $\mathrm{R}_{\text {rup }}$ の関係を示す。 $\mathrm{Mw}$ は $3.7 \sim 8.2, \mathrm{R}_{\text {rup }}$ は 1.2 250km の範囲にある。佐藤・他 ${ }^{14)}$, Satoh et al.3)で, 用いられている地震以外は 15) 21)の文献の断層モデルの $\mathrm{Mw}, \mathrm{R}_{\mathrm{rup}}$ を用いた。震源深さ $\mathrm{H}$ は, 地震モーメントで重みづけし
た断層中心深さである。断層モデルがない地震の, 震源位置は気象 庁の一元化震源情報とし, Mw は F-net, F-net がない地震は Global $\mathrm{CMT}$ の值を用いた。解析では $\mathrm{S}$ 波部以降の波を対象としている。 群遅延時間の平均值・分散の予測式作成では, $\mathrm{S}$ 波部以降の波の観 測継続時間が 80 秒以下の記録と絶対時刻が不明の記録は除いた。 そのため, データはやや減少している。減衰定数 $5 \%$ の加速度応答 スペクトルは, 水平 2 成分の幾何平均, 群遅延時間の平均值・分散 は水平 2 成分の算術平均を用いた。超高層建築物の設計用入力地震 動策定に用いることを目指しているため, 主たる対象は周期 $1 \sim 10$ 秒であるが，同じ考え方で周期 $0.1 〜 1$ 秒も検討している。

\section{（2）予測式作成手法}

固有周期 $\mathrm{T}$ での減衰定数 $5 \%$ の加速度応答スペクトル $\mathrm{S}_{\mathrm{A}}(\mathrm{T})$ を,

(1)〜(4)式でモデル化する。

$\log _{10} \mathrm{~S}_{\mathrm{A}}(\mathrm{T})=\mathrm{Sou}(\mathrm{T})+\mathrm{b}(\mathrm{T}) \mathrm{R}_{\text {rup }}$

$$
-\log _{10}\left(\mathrm{R}_{\text {rup }} 2+\left(\mathrm{d}(\mathrm{T}) 10^{0.25 \mathrm{Mw}) 2}\right)^{0.5}+\mathrm{c}_{0}(\mathrm{~T})+\mathrm{c}_{\mathrm{j}}(\mathrm{T})\right.
$$

ここで, 震源項 $\mathrm{Sou}(\mathrm{T})$ は,

$\operatorname{Sou}(\mathrm{T})=\mathrm{a}_{1}(\mathrm{~T}) \mathrm{M}_{\mathrm{w}}+\mathrm{a}_{4}(\mathrm{~T}) P \log _{10} \mathrm{H}+\mathrm{a}_{5}(\mathrm{~T}) S \operatorname{Sog}_{10} \mathrm{H} \quad \mathrm{M}_{\mathrm{w}} \leqq \mathrm{M}_{\mathrm{h}}(\mathrm{T})(2)$ $=\mathrm{a}_{1}(\mathrm{~T}) \mathrm{M}_{\mathrm{w}}+\mathrm{a}_{2}(\mathrm{~T})\left(\mathrm{M}_{\mathrm{w}}-\mathrm{M}_{\mathrm{h}}(\mathrm{T})\right)$

$+\mathrm{a}_{4}(\mathrm{~T}) P \log _{10} \mathrm{H}+\mathrm{a}_{5}(\mathrm{~T}) S \log _{10} \mathrm{H} \quad \mathrm{M}_{\mathrm{h}}(\mathrm{T}) \leqq \mathrm{M}_{\mathrm{w}} \leqq \mathrm{M}_{\mathrm{h} 2}(\mathrm{~T})(3)$ $=\mathrm{a}_{1}(\mathrm{~T}) \mathrm{M}_{\mathrm{w}}+\mathrm{a}_{2}(\mathrm{~T})\left(\mathrm{M}_{\mathrm{w}}-\mathrm{M}_{\mathrm{h}}(\mathrm{T})\right)+\mathrm{a}_{3}(\mathrm{~T})\left(\mathrm{M}_{\mathrm{w}}-\mathrm{M}_{\mathrm{h} 2}(\mathrm{~T})\right)$

$+\mathrm{a}_{4}(\mathrm{~T}) P \log _{10} \mathrm{H}+\mathrm{a}_{5}(\mathrm{~T}) S \log _{10} \mathrm{H} \quad \mathrm{M}_{\mathrm{w}} \geqq \mathrm{M}_{\mathrm{h} 2}(\mathrm{~T})(4)$ ここで, $P, S$ は, ダミー変数(プレート境界地震で $P=1, S=0$, スラ ブ内地震で $P=0, S=1$ )であり, 震源深さ $\mathrm{H}$ 依存のモデル化とした。 $\mathrm{M}_{\mathrm{h}}, \mathrm{M}_{\mathrm{h} 2}$ はヒンジマグニチュード 10),11)である。その他の小文字の係 数が回帰係数であり, $\mathrm{c}_{\mathrm{j}}$ は $\mathrm{j}$ 観測点でのサイト係数である。 $\mathrm{c}_{0}$ は, TKYH13(檜原南)での地盤同定結果に基づく, 地震基盤相当でのサ イト係数である。10 cjを地震基盤から地表までの地盤増幅率と呼ぶ。 震源近傍での飽和に関する(1)式第 3 項は, Atkinson and Silva ${ }^{22) や ~}$ Yenier and Atkinson ${ }^{23)}$ に基づきモデル化した。相模卜ラフ沿いのプ レート境界地震, スラブ内地震の $\mathrm{Q}$ 值がほぼ同じと推定されている 24)ため, プレート境界地震とスラブ内地震で b の区別はしない。

回帰係数は, 二段階回帰分析とグリッドサーチにより求めた。一 段階目では, (1)式を用いて, 地殼内地震のデータも含め, 地殼内地 震と海溝型地震それぞれの $\mathrm{b}$ とその他の項を推定する。地殼内地震 のデータに対しては, 距離が $\mathrm{R}_{\lim }(\mathrm{T})$ より遠いところで, 減衰が小さ くなる特徴をモデル化するため, $\mathrm{R}_{\mathrm{rup}}>\mathrm{R}_{\lim }(\mathrm{T})$ では, $\mathrm{R}_{\text {rup }}$ の代わりに

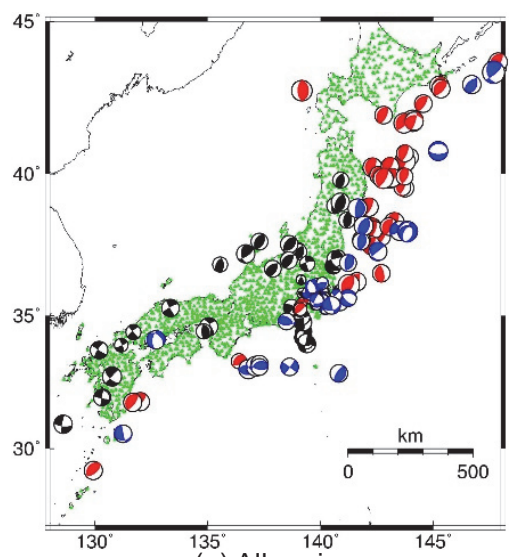

(a) All region

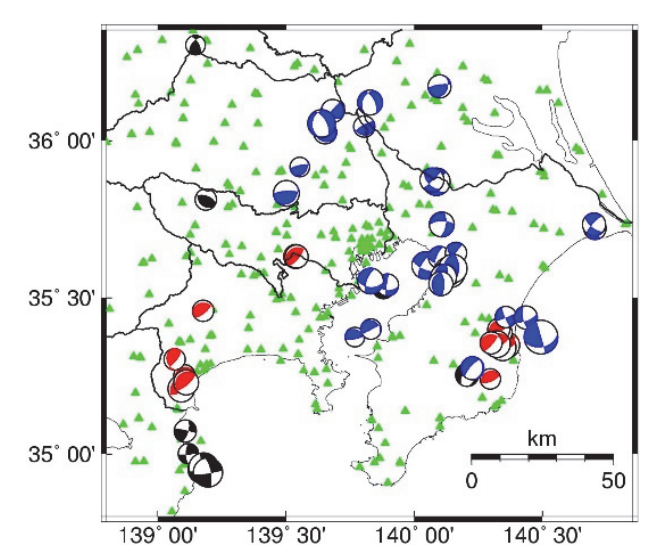

(b) Close up the south Kanto region

Fig.1 Locations of strong motion stations (green), the epicenters (JMA) with CMT solutions (F-net or Global CMT) of interplate (red), intraplate (blue), and crustal (black) earthquakes

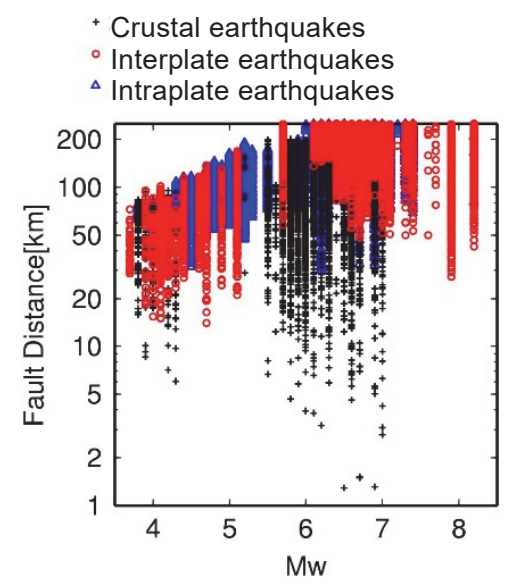

Fig.2 Relation between $\mathrm{Mw}$ and fault distance $R_{\text {rup }}$ 
$\left(\mathrm{R}_{\text {rup }} \times \mathrm{R}_{\lim }(\mathrm{T})\right) 0.5$ とした ${ }^{25)}$ 。既往の研究 ${ }^{3), 25)}$ に基づき, $\mathrm{d}$ は $0 \sim 0.8$ まで 0.05 刻み, $\mathrm{R}_{\lim }$ は $50 \sim 100 \mathrm{~km}$ まで $10 \mathrm{~km}$ 刻みのグリッドサー チにより求めた。観測の震源項 Sou に基づき, $\mathrm{M}_{\mathrm{h}}$ は 5.5〜 6.5, $\mathrm{M}_{\mathrm{h} 2}$ は $6.5 \sim 7.5$ の範囲を 0.1 刻みとしたグリッドサーチにより求めた。 二段階目では, 海溝型地震のデータのみを用い, 一段階目で得られ た観測の震源項 Sou を(2)〜(4)式でモデル化し，(1)式に代入して回 帰分析を行った。なお, 1987 年千葉県東方沖地震の記録は, 1 地点 を除き, 他の地震の記録が得られていないが, 首都直下地震として 重要であることから，(1)式のこの地震の観測の震源項 Sou を用い て $c_{j}$ を求め直した。

群遅延時間の平均值 ・分散 $\mathrm{Z}(\mathrm{T})$ は, Satoh et al. 3)の式に $\mathrm{A}_{2}$ を加 えた, (5)式でモデル化し, 非負条件付き最小二乗法 ${ }^{26}$ )により回帰係 数を推定した。

$\mathrm{Z}(\mathrm{T})=\mathrm{A}_{1}(\mathrm{~T}) \mathrm{M}_{0}{ }^{1 / 3}-\mathrm{A}_{2}(\mathrm{~T})+\mathrm{B}(\mathrm{T}) \mathrm{X}+\mathrm{C}_{\mathrm{j}}(\mathrm{T})$

ここで, $\mathrm{M}_{0}$ は地震モーメント, $\mathrm{X}$ は震源距離である。 $\mathrm{A}_{1}, \mathrm{~A}_{2}, \mathrm{~B}, \mathrm{C}_{\mathrm{j}}$ が回帰係数であり, $\mathrm{C}_{\mathrm{j}}$ は $\mathrm{j}$ サイトのサイト係数である。群遅延時間 の標準偏差のサイト係数は $\mathrm{C}_{\mathrm{j}} 0.5$ である。 $\mathrm{A}_{2}$ はスラブ内地震の係数で あり, プレート境界地震では 0 である。佐藤 24)で, 相模卜ラフ沿い の中規模地震記録の分析から, 周期 1 秒以上ではスラブ内地震の方 がプレート境界地震より後続波の励起が小さく, $0.1 \sim 1$ 秒では同程 度であることを指摘していることを踏まえて, 一 $\mathrm{A}_{2}$ としている。

\section{3. 予測式の回帰係数}

Fig.3 には, $\mathrm{S}_{\mathrm{A}}$ の回帰係数を標準偏差 $\mathrm{e}$ とともに示す。深さに関 寸る回帰係数 $\mathrm{a}_{4}, \mathrm{a}_{5}$ は, 長周期で負となっている。例えば, 周期 1 秒では $\mathrm{a}_{4}=0.13$ であり, これを(1)〜(4)式に代入すると, $\mathrm{H}=20 \mathrm{~km}$ で の $\mathrm{S}_{\mathrm{A}}$ は $\mathrm{H}=50 \mathrm{~km}$ の 0.89 倍となる。周期 10 秒での $\mathrm{a}_{4}=-0.23$ を用 いると, $\mathrm{H}=20 \mathrm{~km}$ での $\mathrm{S}_{\mathrm{A}}$ は $\mathrm{H}=50 \mathrm{~km}$ の 1.23 倍となる。これは,
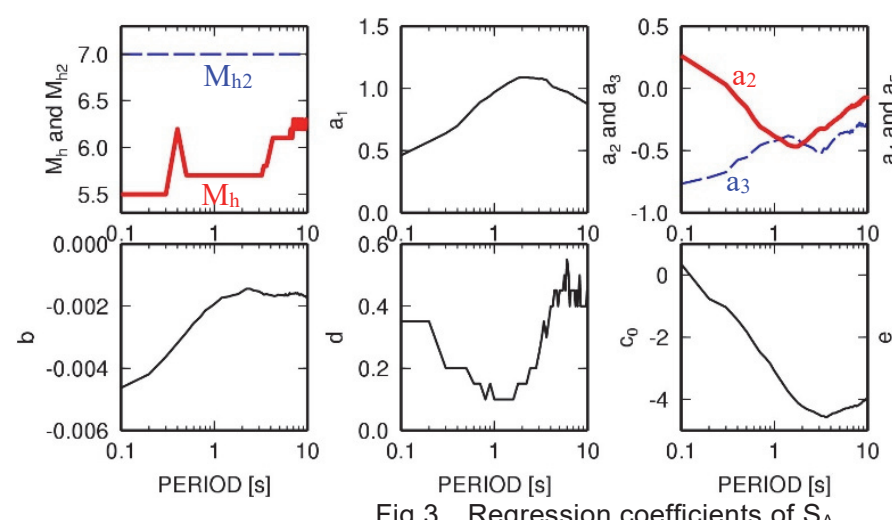

Fig.3 Regression coefficients of $\mathrm{S}_{\mathrm{A}}$

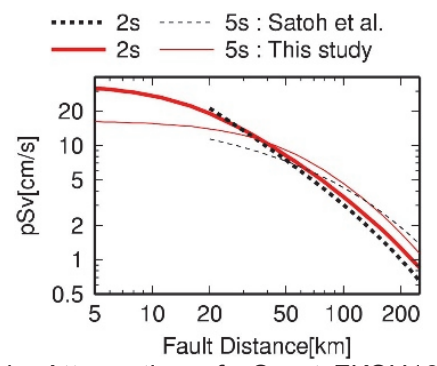

Fig.4 Attenuation of pSv at FKSH19 for a Mw8.0 interplate earthquake with $\mathrm{H}=20 \mathrm{~km}$ by Satoh et al.(2014) and this study
長周期で卓越する表面波が, 浅いほど励起が大きいためと考えられ る。短周期で $\mathrm{a}_{5}$ の方が $\mathrm{a}_{4}$ より大きいのは, スラブ内地震の短周期 レベルの深さ依存性 ${ }^{27)}$ が反映されたものと考えられる。 $\mathrm{M}_{\mathrm{h}}$ は, 周 期 1 秒以上で 5.7 から 6.3 まで遷移しており, Mw3.0〜 7.9 の地款 内地震のデータを用いている Boore et al. ${ }^{28)}$ 上り遷移域が長周期で ある。これは, 本研究の方が $\mathrm{Mw}$ の大きいデータが多いためと考え られる。飽和の係数 $\mathrm{d}$ は, 周期 1 秒以上では周期が長いほど大きく なり, 周期 4 10 秒でほぼ一定となる。すなわち, 周期 4〜10 秒で は, 周期 1〜4 秒に比べて, 震源から遠いところから飽和する。Fig.4 には, $\mathrm{Mw} 8, \mathrm{H}=20 \mathrm{~km}$ のフィリピン海プレートの地震に対する Satoh et al. ${ }^{3)}$ と本研究の式の周期 2 秒と 5 秒での距離減衰の比較を 示す。Satoh et al. ${ }^{3)}$ の式の基準観測点である FKSH19(都路)での例 である。本研究と Satoh et al. ${ }^{3)}$ の式では予測式のモデル化が若干異 なっているが, 距離減衰の違いは小さい。

Fig.5 には, 周期 2 秒でのプレート境界地震に対する観測とモデ ルの震源項 Sou を示す。 $M_{\mathrm{h}}, \mathrm{M}_{\mathrm{h} 2}$ を導入したことにより, 観測の震 源項 Sou が広い Mw の範囲で良くモデル化されていることがわか る。 $\mathrm{H}=20 \mathrm{~km}$ と $50 \mathrm{~km}$ の場合のモデルを示しているが， $\mathrm{a}_{4}$ が周期 2 秒でほぼ 0 である(Fig.3)ため重なっている。

Fig.6 には, 群遅延時間の平均值・分散に対寸る回帰係数と回帰の 標準偏差 E を示す。南海トラフ沿いの地震に対する Satoh et al. ${ }^{3)} の$ 式の回帰係数も Fig. 6 に示した。本研究の群遅延時間の平均值の $\mathrm{A}_{1}$ は周期 1 秒付近で極小值を持ち, Satoh et al.3) とやや異なるが, こ の違いの原因は不明である。この $\mathrm{A}_{1}$ の周期 1 秒での違いについて,

Mw7 を例に考えると, (5)式の震源項 $\mathrm{A}_{1} \mathrm{M}_{0}{ }^{1 / 3}$ の周期 1 秒と 10 秒で の差が本研究では 7.5 秒であるのに対して Satoh et al.3)では 5.1 秒 となり, 本研究の方が震源項での周期による波群の伝播時間の違い
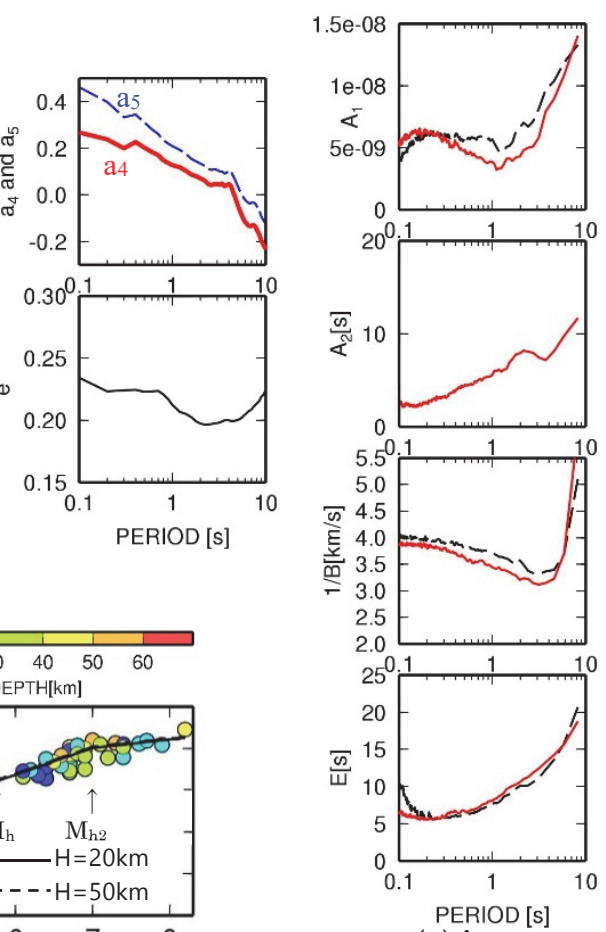

(a) Average

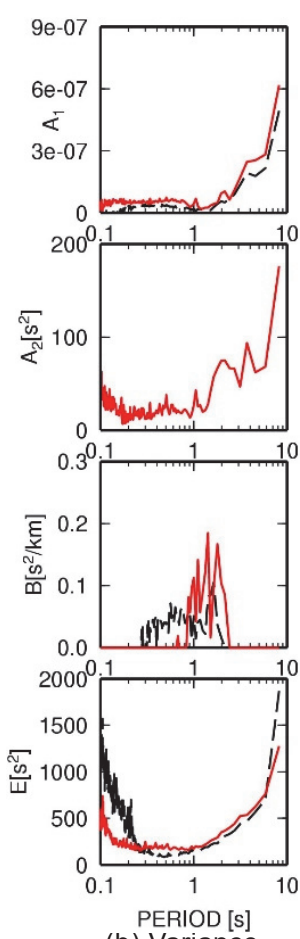

(b) Varian [s] Fig.6 Regression coefficients of average and variance of group delay time obtained in this study (bold red lines) and Satoh et al. ${ }^{3)}$ (dashed lines) 
が大きく継続時間が伸びる方向に寄与する。しかし, 関東平野内で の群遅延時間の平均值のサイト係数 $\mathrm{C}_{\mathrm{j}}$ は概衫 30 秒程度以上である ため, 群遅延時間の平均值 $\mathrm{Z}(\mathrm{T})$ に対する影響は小さい。群遅延時間 の平均值の $\mathrm{A}_{2}$ は長周期ほど大きく, これは, スラブ内地震の方がプ レート境界地震より長周期成分の波群の重心が前にあることを意味 している。群遅延時間の分散の $\mathrm{A}_{2}$ も長周期ほど大きく, これは, ス ラブ内地震の方が長周期成分の波群の広がりが短いことを意味して いる。これらの特徵は, スラブ内地震の方がプレート境界地震より 震源深さが梁く, 表面波の励起が小さいことを反映していると考え られる。

\section{4. サイト特性}

予測式作成に用いた関東地域の観測点間隔は, Fig.1(b)に示した ように，東京都東部を除き $10 \mathrm{~km}$ 前後である。そこで, SK-net ${ }^{29}$ の データを追加し, サイト係数 $\mathrm{c}_{\mathrm{j}}, \mathrm{C}_{\mathrm{j}}$ の算出地点を密にした。予測式 作成に用いたデータと同じ条件で選択した SK-net ${ }^{29)}$ のデータを用 いて, 3.で得られた予測式のサイト係数以外の回帰係数から得られ る SK-net 観測点でのサイト係数 $\mathrm{C}_{\mathrm{j}}, \mathrm{C}_{\mathrm{j}}$ を, 各観測点で平均するこ とにより算出している。 $\mathrm{S}_{\mathrm{A}}$ の予測式作成に用いた海溝型地震の地震 観測点ペア数は約 13000 , 地凯内地震は約 11000 であるのに対して, SK-net の海溝型地震の地震観測点ペア数は約 12000 である。Fig.7 には, SK-net 観測点を加えた全観測点での, 周期 2 秒での地震基盤 から地表までの地盤増幅率を示す。Fig.1(b) と比べ, 観測点が密にな っていることがわかる。
次に, 地表での観測波形から, 防災科学技術研究所の 1 都 6 県で

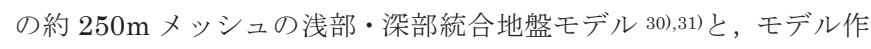
成に用いられている K-NET, KiK-net 直下での浅部地盤モデルを 用いて, 工学的基盤での波形を 1 次元波動理論に基づき算出した。 そして, 各観測点において, 地表での応答スペクトルと工学的基盤 での応答スペクトルの比の平均值で, 地表での地盤増幅率を補正し て, 工学的基盤での地盤増幅率を算出した。本研究では, $\mathrm{S}$ 波速度 $\mathrm{Vs}=400 \mathrm{~m} / \mathrm{s}$ 層を工学的基盤と定義している。Q 值は, $\mathrm{Vs} / 10 \mathrm{f}^{0.44}$ (周 波数 $\mathrm{f}>5 \mathrm{~Hz}$ で一定 $)^{31}$ とした。なお, 浅部・深部統合地盤モデルは, 地震本部(HERP) 32 )から公開されているモデルとは若干異なる。

Fig.8には, 浅部・深部統合地盤モデルの工学的基盤から地表まで の各層の層厚と Vs から $1 / 4$ 波長則に基づき算出した, 浅部地盤の 略算の固有周期 Ts を示寸。図中の観測点は, 地盤増幅率の例を示す 観測点である。固有周期が 1 秒以上の地域が広がっており, 周期 1 秒以上の長周期でも浅部地盤の増幅特性の影響があることがわかる。 Fig.9 には, 周期 2 秒での工学的基盤での地盤増幅率を示す。Ts が 長い領域で, 地表(Fig.7)に比べて工学的基盤の地盤増幅率が面的に やや平坦になっている。浅部地盤が寄与する表面波の影響は取り除 けないが， $\mathrm{S}$ 波の一次元地盤増幅が取り除かれているためである。

Fig.10には, TKY007(新宿)と KNG002(横浜)における地表と工 学的基盤での応答スペクトルの地盤増幅率と, 3 種類の一次元理論 地盤増幅率を示す。TKY007 では, 工学的基盤から地表までの理論 地盤増幅率の最大ピーク周期が約 0.15 秒であるため, 周期 1 秒以 上では地表と工学的基盤での地盤増幅率はほぼ同じである。

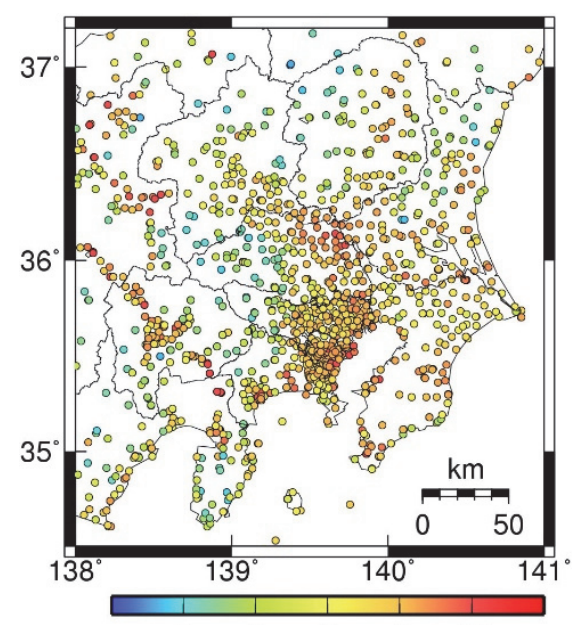

Fig.7 Amplification factors at the surface at $2 \mathrm{~s}$

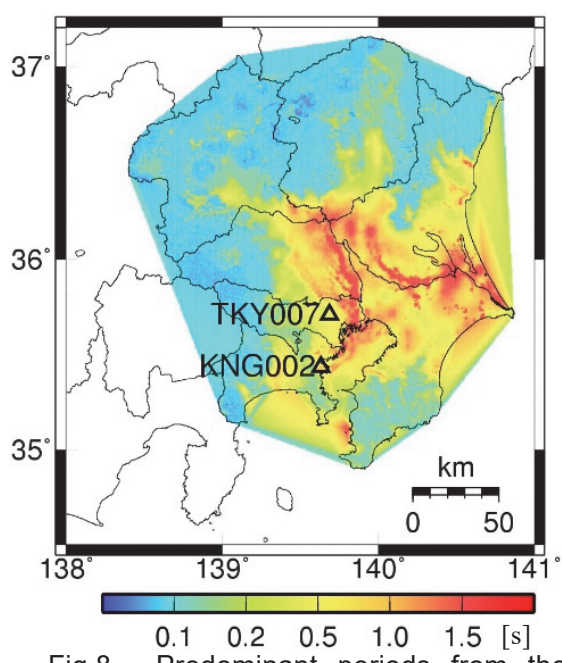

Fig.8 Predominant periods from the engineering bedrock to the surface (Ts)

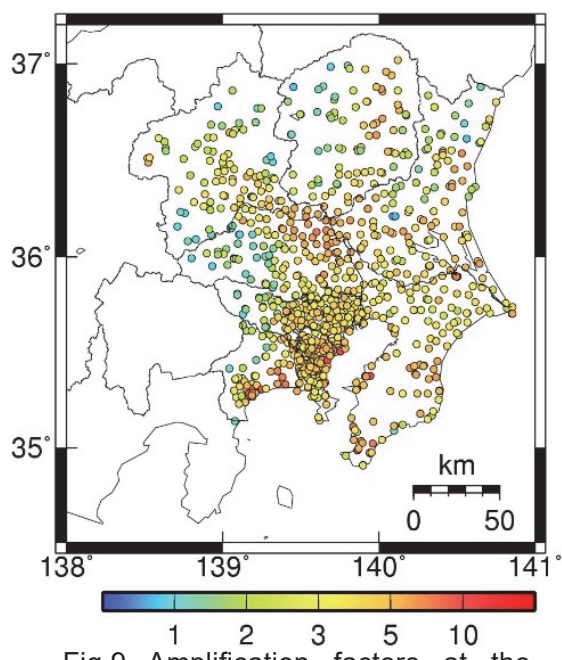

Fig.9 Amplification factors at the engineering bedrock at $2 \mathrm{~s}$

....-1D theory from seismic bedrock to engineering bedrock

- - - Estimated at engineering bedrock

-- 1D theory from engineering bedrock to surface

- 1D theory from seismic bedrock to surface

- Observed at surface

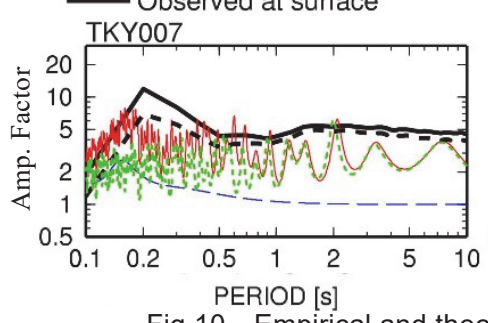

Fig.10 Empirical and theoretical amplification factors

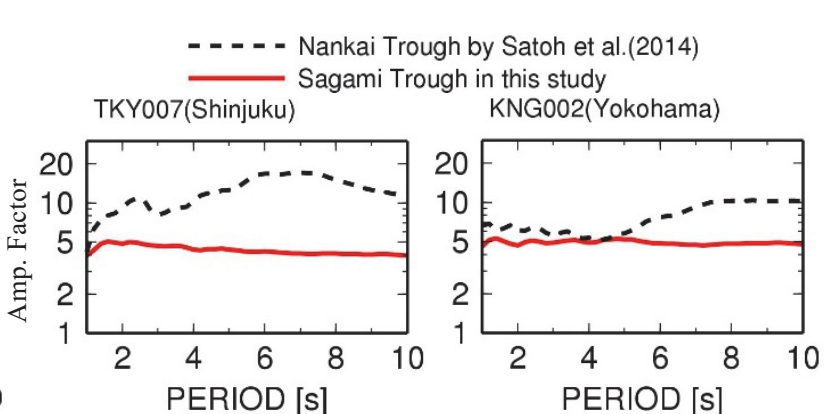

Fig.11 Amplification factors at the engineering bedrock in this study and by Satoh et al. ${ }^{3)}$ 
TKY007 でのTs 40.47 秒であるが, 一次元波動理論ではインピー ダンスコントラストが大きい極浅部の地盤の増幅により最大ピーク が生じている。KNG002 では, 工学的基盤から地表までの理論地盤 増幅率の 1 次卓越周期が約 1 秒であるため, 工学的基盤での応答ス ペクトルの地盤増幅率は 1 秒を中心に地表より小さくなっている。

Fig.11には, 本研究と Satoh et al. ${ }^{3}$ の南海トラフ沿いの地震に対 する予測式の, 工学的基盤での地盤増幅率の比較を示す。Satoh et al. ${ }^{3)}$ の関東平野での地盤増幅率は, フィリピン海プレートの地震と 太平洋プレートの地震を区別しており，ここに示したのはフィリピ ン海プレートの地震に対するものである。また, 地殼内地震の地盤 増幅率との地震数による重み付き平均である。本研究の地盤増幅率 は, Satoh et al. ${ }^{3}$ に比べて小さく, 周期依存性も小さい。このよう な特徵が, 関東地域の他の観測点でもみられた。藤原・他 ${ }^{32}$ は, 複 数のシナリオの相模トラフ沿いの地震に対する三次元有限差分法に よる地盤増幅率や, 相模トラフ沿いの中規模地震の観測記録に基づ く地盤増幅率を求め, Satoh et al.3)の地盤増幅率より小さいことを 示している。藤原・他 ${ }^{33)}$ の地盤増幅率は本研究の地盤増幅率とほぼ 同レベルであり, 周期特性が小さい特徵も類似している。また, 藤
原・他 ${ }^{33}$ は, 大正関東地震の震源域より北側の中規模地震の記録を 用いた分析ではあるものの, 震源位置により長周期の増幅率が異な ることも指摘している。したがって, 本研究も藤原・他 ${ }^{33)}$ の地盤増 幅率も, 種々の方向から伝播する地震に対する平均的なものであり, 周期特性が平滑化されている可能性がある。また, 本研究と Satoh et al.3)の違いも, 震源位置の違いによる表面波の励起特性の違いを 反映したものと考えられる。本研究の地震動予測式では, 巨視的断 層面を用いているため, 平均的な地盤増幅率は有効であると考えら れるが，ばらつきを如何に取り込むかについては課題である。

群遅延時間の平均值・標準偏差に対しても, 同様にして工学的基 盤でのサイト係数を算出したが, 地表と工学的基盤でのサイト係数 の違いはほとんどなかった。Fig.12 には, 周期 5 秒における工学的 基盤での地盤増幅率 $\mathrm{C}^{\mathrm{E}}$ と群遅延時間の平均值・標準偏差のサイト 係数 $\mathrm{C}_{\mathrm{tgr}} \mathrm{E}$ を示す。(a)の周期 5 秒の地盤増幅率は, Fig.9 の周期 2 秒 の地盤増幅率と類似の分布をしており, 振幅レベルの違いも小さい。 (b)の群遅延時間の平均值のサイト係数は, Fig.8 の浅部地盤の固有 周期 Ts が 1 秒以上の領域で大きい傾向がある。(c)の群遅延時間の 標準偏差のサイト係数にも, 顕著ではないが同様の傾向がみられる。

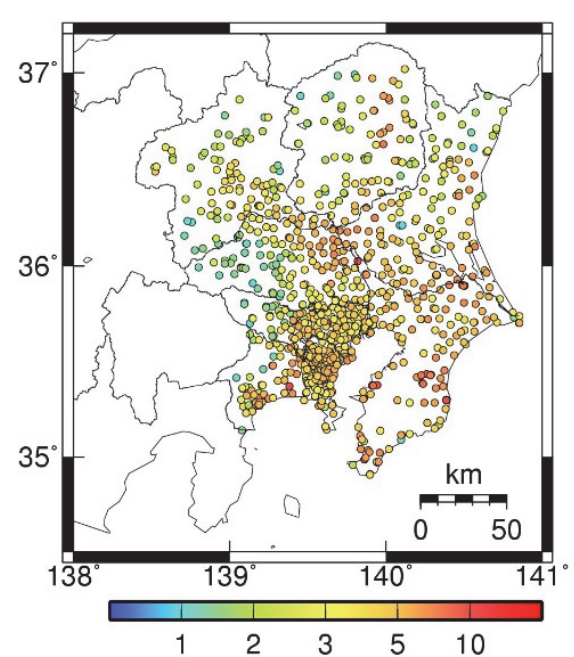

(a) Amplification factors for $S_{A}$

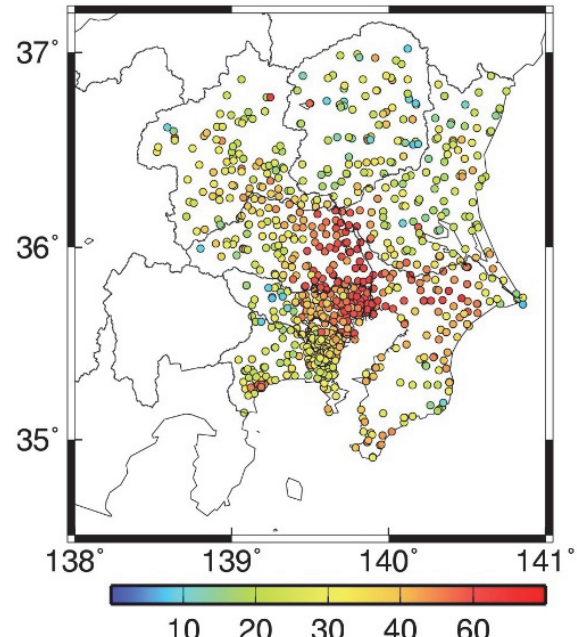

(b) Average of group delay time

Fig.12 Site coefficients at the engineering bedrock at $5 \mathrm{~s}$

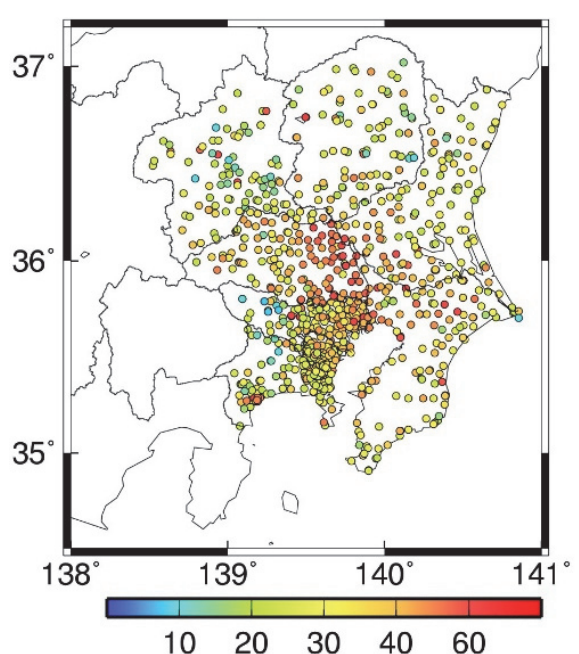

(c) Standard deviation of group delay time

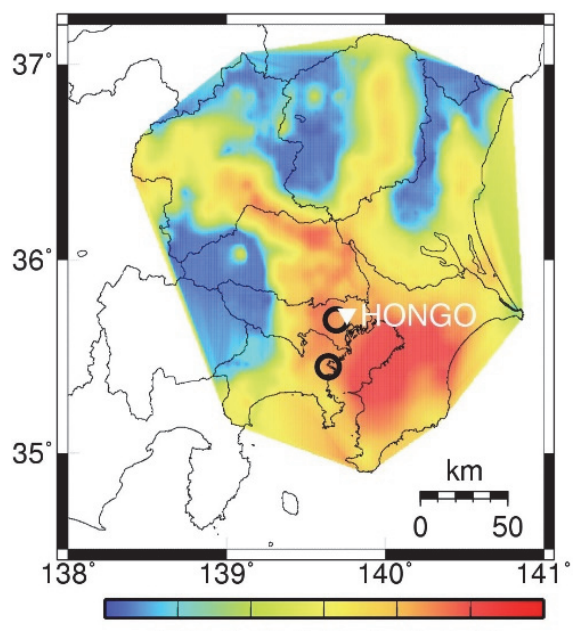

$\begin{array}{lllll}0.25 & 0.50 & 1.00 & 2.00 & 3.00\end{array}$

Fig.13 Tz from the seismic bedrock to the engineering bedrock (Circles indicate Tokyo metropolitan government and Kanagawa prefectural government shown in Fig.18)

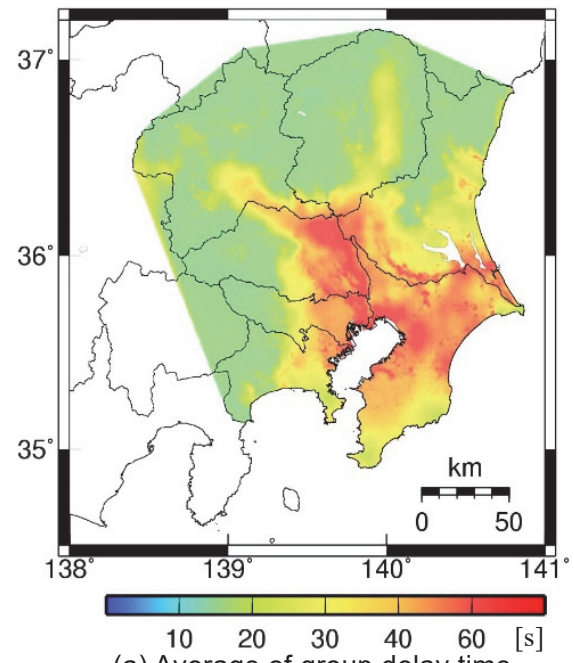

(a) Average of group delay time Fig.14 Model site coefficients at 5s

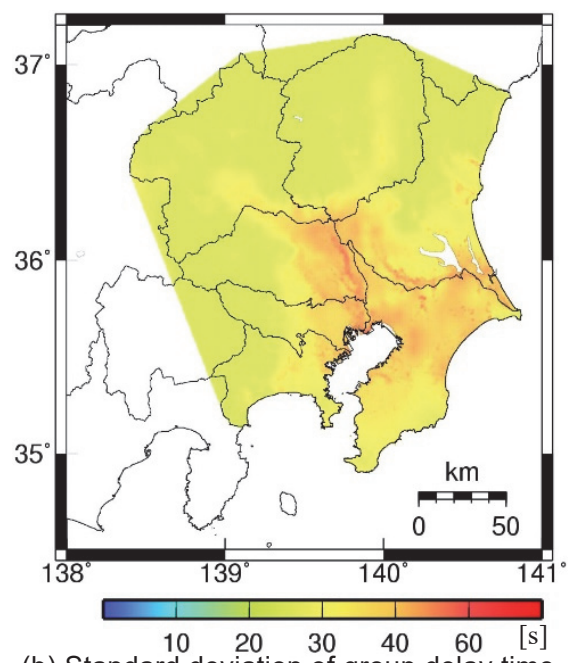

(b) Standard deviation of group delay time 

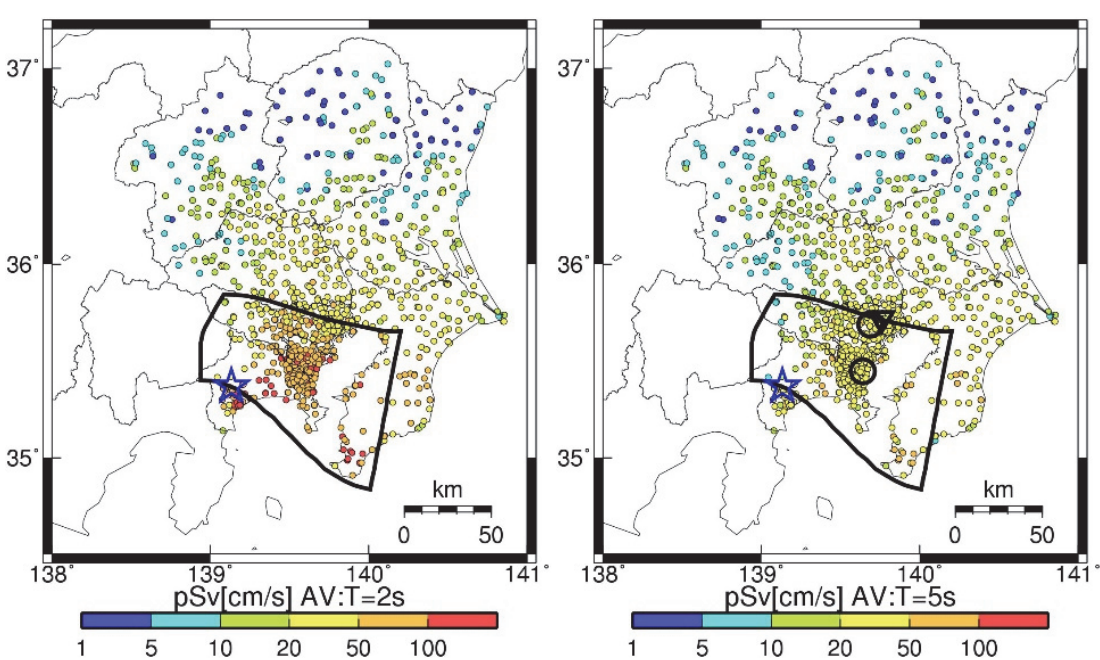

Fig.15 pSv predicted for T1-type earthquake (Mw7.9) at $2 \mathrm{~s}$ and $5 \mathrm{~s}$ (Bold lines denote fault mode ${ }^{9}$. Stars denote the epicenter ${ }^{9}$. A triangle indicates Hongo. Circles indicate Tokyo metropolitan government and Kanagawa prefectural government.)

Fig.13 には, 浅部・深部統合地盤モデルに基づく, $\mathrm{Vs}=3.2 \mathrm{~km} / \mathrm{s}$ の 地震基盤から工学的基盤までの $\mathrm{Tz}^{4}$ )を示す。図中には，後述の大正 関東地震に対する計算地点も示している。佐藤・他 ${ }^{4}$ は, $\mathrm{C}^{\mathrm{E}}, \mathrm{C}_{\mathrm{tg}} \mathrm{E}$ を $\mathrm{Tz}$ でモデル化しているが， $\mathrm{C}_{\mathrm{tgr}} \mathrm{E}$ は $\mathrm{Tz}$ のみでのモデル化では十 分でないと考えられる。

$$
\text { そこで， } \mathrm{C}_{\mathrm{tgr}} \mathrm{E} \text { は } \mathrm{Tz} \text { と } \mathrm{Ts} \text { を用いて，(6)式でモデル化を行った。 }
$$

$\mathrm{C}_{\mathrm{tgr}} \mathrm{E}(\mathrm{T})=\mathrm{r}_{0}(\mathrm{~T})+\mathrm{r}_{1}(\mathrm{~T}) \mathrm{Tz}+\mathrm{r}_{2}(\mathrm{~T}) \mathrm{Ts}$

$$
0.2 \leqq \mathrm{Tz} \leqq 2.77(6)
$$

ここで, $\mathrm{Tz}<0.2 \mathrm{~s}$ では $\mathrm{Tz}=0.2 \mathrm{~s}$ の值で一定である。千葉県のデータ のみとなる $\mathrm{Tz}>2.77 \mathrm{~s}$ では $\mathrm{C}_{\mathrm{tgr}} \mathrm{E}$ がほぼ一定であったため, $\mathrm{Tz}=$ $2.77 \mathrm{~s}$ の值で一定とした。 $\mathrm{r}_{0}, \mathrm{r}_{1}$ が回帰係数である。加速度応答スペ クトルの $\mathrm{CE}^{\mathrm{E}}$ は $\mathrm{Tz}$ を用いて(7)，(8)式でモデル化を行なった。

$$
\begin{array}{rlrl}
\log _{10} \mathrm{CE}(\mathrm{T}) & =\mathrm{p}_{0}(\mathrm{~T})+\mathrm{p}_{1}(\mathrm{~T}) \mathrm{Tz} & 0.2 \leqq \mathrm{Tz} \leqq 1.0 \\
& =\mathrm{p}_{0}(\mathrm{~T})+\mathrm{p}_{1}(\mathrm{~T})+\mathrm{p}_{2}(\mathrm{~T})(\mathrm{Tz}-1.0) & 1.0<\mathrm{Tz} \leqq 3.51
\end{array}
$$

ここで, $\mathrm{Tz}<0.2 \mathrm{~s}$ では $\mathrm{Tz}=0.2 \mathrm{~s}$ の值で一定であり，観測の $\mathrm{Tz}$ の最 大值 $3.51 \mathrm{~s}$ 以上では $\mathrm{Tz}=3.51 \mathrm{~s}$ の值で一定であるとした。 $\mathrm{p}_{0}, \mathrm{p}_{1}$, $\mathrm{p}_{2}$ が回帰係数である。なお, $\mathrm{C}^{\mathrm{E}}$ は, 周期 3 秒以下は直下の地盤モデ ルを用いている K-net, KiK-net 観測点のみを用い, 3 秒より長周 期では全観測点のデータを用いた。 $\mathrm{C}_{\mathrm{tgr}} \mathrm{E}$ は, 地表と工学的基盤での サイト係数の差がほとんどないことから全観測点のデータを用いた。

Fig.14 には, 周期 5 秒におけるモデル化された $\mathrm{C}_{\mathrm{tgr}} \mathrm{E}$ を示す。 Fig.12の観測 $\mathrm{C}_{\mathrm{tgr}} \mathrm{E}$ が，Tzと Ts を用いた(6)式でほぼ再現できるこ とがわかる。(6)〜(8)式を用いることにより, 浅部・深部統合地盤モ デルを用いて, 1 都 6 県では, 約 $250 \mathrm{~m}$ 間隔で予測が可能となった。 観測 $\mathrm{C}_{\mathrm{tgr}} \mathrm{E}$ が $\mathrm{Ts}$ と相関が高いのは, 浅部地盤の固有周期より長い周 期でも, 表面波が深部地盤と浅部地盤の影響を受けて, 波群の重心 が遅れて到達し, 継続時間が伸びるためと考えられる。Hatayama et al. ${ }^{33}$ は, 2003 年十勝沖地震の K-NET 苫小牧付近での周期 7 秒 の卓越に $\mathrm{Vs}_{\mathrm{s}}=800 \mathrm{~m} / \mathrm{s}$ 層以浅が寄与した表面波の影響を指摘してい る。Hatayama et al. ${ }^{33)}$ の指摘は, 振幅に対するものであるが, 最大 值指標である $\mathrm{S}_{\mathrm{A}}$ より継続時間の方が表面波の影響を受けやすいた め, $\mathrm{C}_{\mathrm{tgr}} \mathrm{E} に$ 浅部地盤の影響が強く表れたと考えられる。この結果は, 工学的基盤以深の地下構造モデルを用いた三次元有限差分法では, このような浅部地盤の影響が反映できないことを意味している。

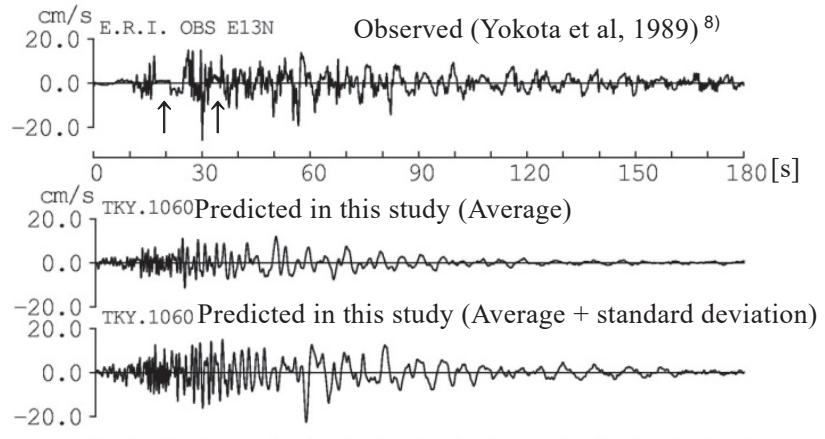

Design spectrum (Level-2)
Av. + Standard deviation in this study

Av. near 5 stations in this study

- Observed (Yokota et al., 1989)

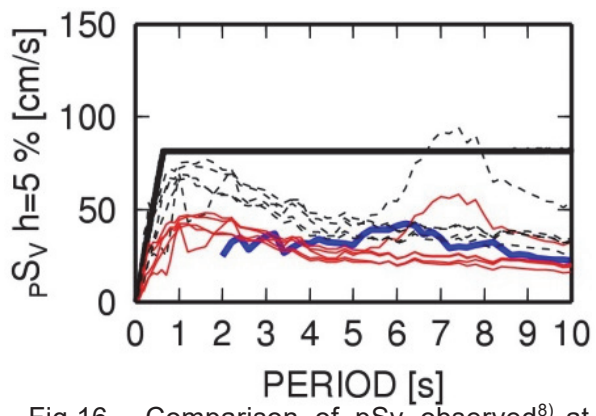

Fig.16 Comparison of pSv observed ${ }^{8)}$ at Hongo and predicted at five stations near Hongo for T1-type earthquake in this study

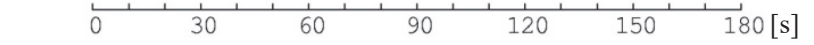

Fig.17 Comparison of velocity waveforms observed at Hongo (Arrows indicate unrestored portions) ${ }^{8)}$ and predicted at a station near Hongo for T1-type earthquake in this study

\section{5. 予測式の適用}

\section{(1) 大正関東地震}

地震本部 9)が三次元有限差分法で長周期地震動を計算している大 正関東地震タイプの震源モデルを用いて, 本研究の予測式により時 刻歷波形を作成した。 $\mathrm{S}_{\mathrm{A}}$ と群遅延時間の平均值・分散の予測式から 時刻歴波形を作成する手法は，佐藤・他 ${ }^{14)}$ と同じである。地震本部 は, T1 タイプで, 本郷での復元波の速度応答スペクトルをほぼ再現 することを示していることから，本研究でも， $\mathrm{T} 1$ タイプ $\left(\mathrm{Mw} 7.9, \mathrm{M}_{0}=8.7 \times 10^{20} \mathrm{Nm}\right)$ の巨視的断層面で, 大正関東地震に相当す る破壊開始点を用いて計算を行った。 $\mathrm{H}=17.5 \mathrm{~km}$ である。

Fig. 15 には, 周期 2 秒と 5 秒での擬似速度応答スペクトル pSv 分 布を用いた断層面と破壞開始点とともに示寸。震源近傍では, 周期 2 秒の方が 5 秒より大きい。Fig.9，Fig.12(a)で示したように周期 2 秒と 5 秒での地盤増幅率の違いは小さく, Fig.4 で示した震源近傍 での距離減衰の違いが表れている。周期 2 秒では, 神奈川県の一部 や千葉県南部の一部で $100 \mathrm{~cm} / \mathrm{s}$ を超えるが, 周期 5 秒では超えない レベルである。Fig.16 には大正関東地震の本郷での復元波 $\left(\mathrm{E} 13^{\circ} \mathrm{N}\right.$ 成分 $)^{8)}$ と, 本郷から $3 \mathrm{~km}$ 以内の 5 観測点での, 予測式の平均および 平均十標準偏差 $\mathrm{e} の \mathrm{pSv}$ の比較を示寸。1 観測点のみ大きいのは本 郷(東大地震研究所)の観測点であり, これは, 1987 年千葉県東方沖 地震の地震のみで地盤増幅率が算出されているためと考えられる。 復元されていない $\mathrm{N} 13^{\circ} \mathrm{W}$ 成分は, 余震記録の分析等から $\mathrm{E} 13^{\circ} \mathrm{N}$ 
成分の 1.5 倍程度と推定されている ${ }^{8)}$ ことを考慮しても予測式で対 象としている水平 2 成分の幾何平均は, 1.2 倍程度である。Fig. 3 か らわかるように, 周期 $1 \sim 10$ 秒で $\mathrm{e}=0.2 \sim 0.23$ であるため, $\mathrm{S}_{\mathrm{A}}$ の平 均 $+\mathrm{e}$ は平均の $1.6 \sim 1.7$ 倍で, 標準偏差の範囲内となる。Fig. 17 に は, 復元波と, 1 地点での周期 $0.5 \sim 10$ 秒の速度波形の平均および 平均十標準偏差の計算波の比較を示す。標準偏差は, $\mathrm{S}_{\mathrm{A}}$, 群遅延時 間の平均值・分散の全てに対して考慮している。なお，復元波の矢 印の 2 か所の欠落部は修復されていない 8)。本震後に多数の余震が 発生しており, 気象庁の一元化震源では, 11 時 58 分 31.7 秒の本震 $\left(\mathrm{M}_{\mathrm{J}} 7.9\right)$ 発生後, 相模湾付近で 12 時 1 分に $\mathrm{M}_{\mathrm{J}} 6.5,12$ 時 3 分に $\mathrm{M}_{\mathrm{J}}$ 7.3 の余震が推定されている。武村 ${ }^{344}$ は, 岐阜測候所での観測波形 から, 本震の約 3 分後に東京湾北部付近で M7.2 の余震が発生した と推定している。この観測波と推定震源位置を考えると, Fig.17の 復元波の $150 \sim 180$ 秒付近以降に余震の影響が含まれているものと 考えられる。また, Mw7.9 としているが，Mw8.0 と推定している 研究もあり 7), Mw8.0 では, 計算波の周期 1〜10 秒での pSv は, Mw7.9 の場合の 1.2 1.3 倍となる。以上のことを考慮すると, 本 研究の計算波は復元波をほぼ再現しているといえる。

Fig.18には, 東京都庁と神奈川県庁での地震本部 9)の T タイプの 公開計算波と, その地点から $1 \sim 3 \mathrm{~km}$ 以内の強震観測点での本研究 の計算波の $\mathrm{pSv}$ の比較を示す。地震本部の計算波は精度が良いとさ
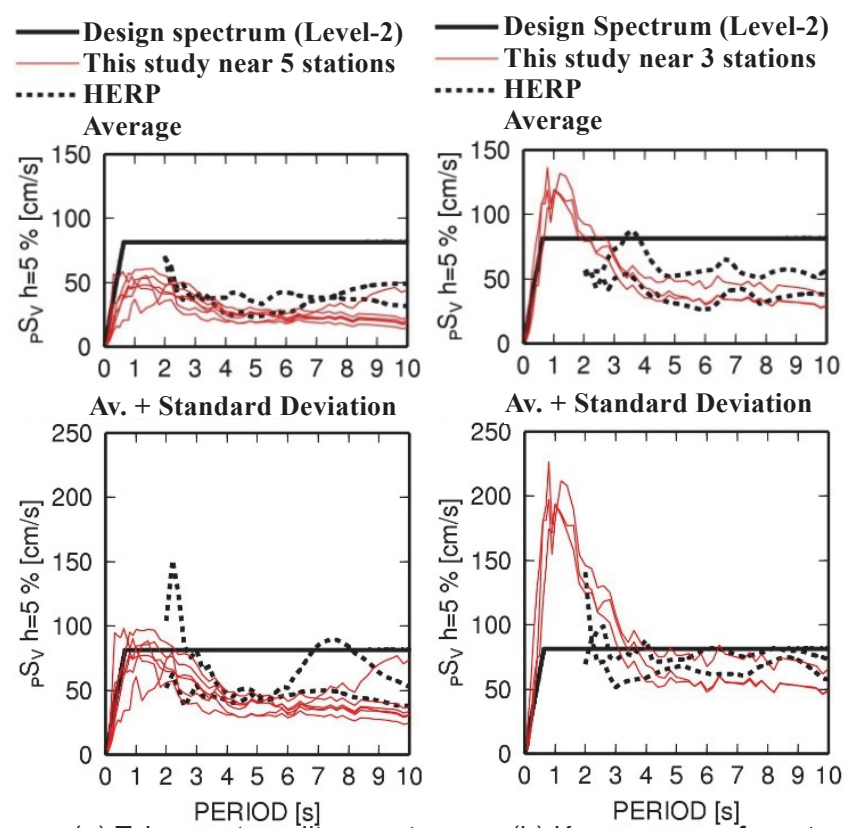

(a) Tokyo metropolitan govt.

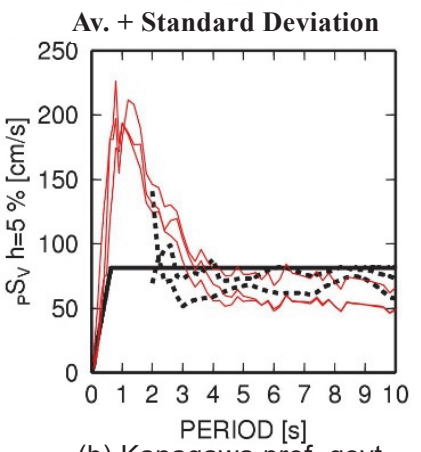

(b) Kanagawa pref. govt.

Fig.18 Comparison of pSv predicted in this study and HERP ${ }^{9}$ for the average (upper) and the average + standard deviation (lower) for the 1923 Taisho Kanto type earthquake

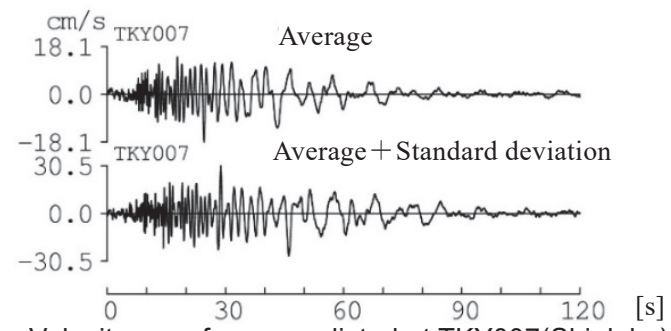

Fig.19 Velocity waveforms predicted at TKY007(Shinjuku) for T1-type earthquake in this study
れている 2 秒以上を示した。地震本部 9)の $\mathrm{T}$ タイプの平均, 平均 + 標準偏差の波は, $\mathrm{T} 1$ タイプ $(\mathrm{Mw} 7.9)$ と $\mathrm{T} 2$ タイプ $(\mathrm{Mw} 8.0)$ の複数の シナリオによる計算波のうち速度応答スペクトルが平均, 平均十標 準偏差に最も近い波の NS 成分と EW 成分である。本研究は $\mathrm{T} 1$ タ イプの平均, 平均十標準偏差の波である。また, 地震本部の計算波 は $\mathrm{Vs}=350 \mathrm{~m} / \mathrm{s}$ 以上の層での計算波であるのに対して, 本研究の計 算波は $\mathrm{Vs}=400 \mathrm{~m} / \mathrm{s}$ 以上の層での計算波である。このような違いも 鑑みると, 地震本部 9) と本研究の計算波のスペクトルレベルは, お おむね対応しているといえる。東京都庁では, 平均, 平均十標準偏 差ともほぼ告示レベル以下である。神奈川県庁では, 平均は周期 2 秒以下で告示よりやや大きく, 平均十標準偏差では周期 3 秒以下で 告示より大きく, 3 秒以上では告示レベルである。東京都庁に近い TKY007(新宿)における, 本研究の $\mathrm{T} 1$ タイプの平均, 平均十標準偏 差の周期 0.1 10 秒の速度波形を Fig. 19 に示寸。最大速度は, 平均 で $18 \mathrm{~cm} / \mathrm{s}$, 平均十標準偏差で $30 \mathrm{~cm} / \mathrm{s}$ である。なお, 地震本部の公 開計算波の破壊開始点は不明のため比較を行っていない。

上述のように，相模トラフ沿いの中規模地震のデータを多数用い ることにより, 伝播経路特性, サイト特性に相模卜ラフ沿いの地震 の特徵を反映させている。しかし, 予測式のデータセットに M8 ク ラスの相模トラフ沿いの地震がないため, 震源特性は, 主として太 平洋プレートの地震に基づいてモデル化されている。そこで, 予測 式の M8 クラスの相模トラフ沿いの地震一の適用性について, 短周 期レベル A を用いて考察する。 Mw8 クラスの地震では, コーナー 周期が 10 秒程度以上となり, 周期 $1 \sim 10$ 秒の加速度震源スペクト ルはほぼ A で説明できると考えられるため, これを $\mathrm{S}_{\mathrm{A}}$ の震源項 $\mathrm{Sou}$ に援用して考察を行う。Fig.20には, 震度をターゲットとして推定 されている大正関東地震の $\mathrm{A}$ と $\mathrm{M}_{0}$ の関係 ${ }^{35)}$, 地震本部 9)の $\mathrm{T} 1$ タ イプ, $\mathrm{T} 2$ タイプの $\mathrm{A}$ (各タイプの 2 種類の震源モデルの $\mathrm{A} の$ 幾何平 均值) と $\mathrm{M}_{0}$ の関係を, 白抜きのシンボルで示す。Fig.20には, 太平 洋プレートのプレート境界地震に対する $\mathrm{M}_{0}-\mathrm{A}$ 関係式 36) も示してい る。佐藤 ${ }^{36)}$ の $\mathrm{M}_{0}-\mathrm{A}$ 関係式で用いられている震源の $\mathrm{S}$ 波速度 $\beta$, 密 度 $\rho$ は, $4.0 \mathrm{~km} / \mathrm{s}, 3.0 \mathrm{~g} / \mathrm{cm}^{3}$ であるが, 大正関東地震 35$)$ や地震本部 9) では, これらより小さい值が用いられている。そこで, 以下のよう にして，この違いを補正した值を色塗りのシンボルで示した。

スペクトルインバージョンでは, 加速度フーリエスペクトルの震 源項 $\mathrm{S}(\mathrm{f})$ は(9)式でモデル化される例えば 36 )。

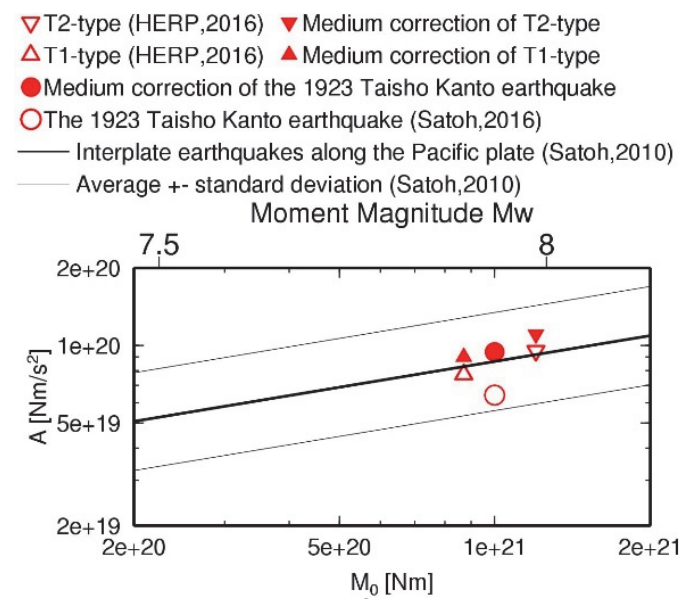

Fig.20 $\quad M_{0}-A$ relations for interplate earthquakes 


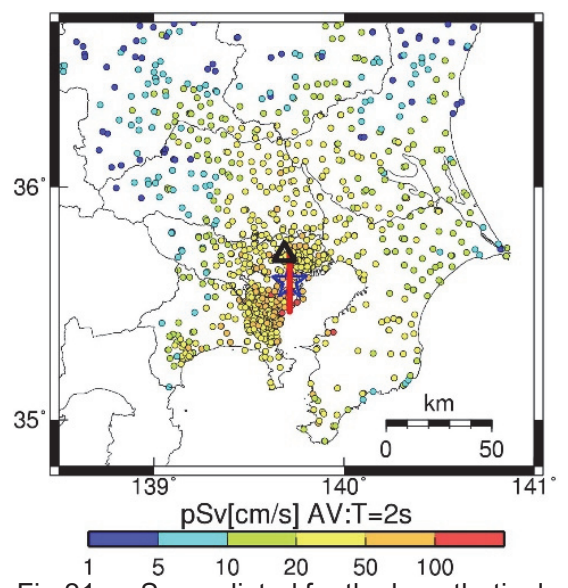

Fig.21 pSv predicted for the hypothetical south Tokyo metropolitan earthquake at 2 $\mathrm{S}$ in this study with locations of TKY007 (triangle), the fault ${ }^{7}$ (red line) and the rupture starting point ${ }^{7)}$ (star).

$$
\mathrm{S}(\mathrm{f})=\frac{\mathrm{c}}{4 \pi \rho \beta^{3}} \sqrt{\frac{\rho \beta}{\rho_{\mathrm{z}} \beta_{\mathrm{z}}}} \mathrm{M}(\mathrm{f})
$$

ここで，加速度震源スペクトル $\mathrm{M}(\mathrm{f})$ は，(10)式である。

$$
M(f)=\frac{(2 \pi f)^{2} M_{0}}{1+\left(\frac{f}{f_{0}}\right)^{2}}
$$

A は(10)式のコーナー周波数 $\mathrm{f}_{0}$ より高周波数での一定レベルである。 定数 $\mathrm{c}$ と地震基盤での $\beta_{z}, \rho_{\mathrm{z}}$ は, 各地震で共通であるため, 地震に よる $\mathrm{S}(\mathrm{f})$ のスペクトル一定レベルの違いは $\mathrm{A} の(\rho \beta)^{0.5} /\left(\rho \beta^{3}\right)$ 倍の違い となる。また, (2)式で求められる各地震の震源項 Sou は, (9)式の $\mathrm{S}$ に対応する。そこで, 佐藤の $\mathrm{M}_{0}-\mathrm{A}$ 関係式 36$)$ で用いられている $\rho, \beta$ に対応するように, $\mathrm{A} を(\rho \beta)^{0.5} /\left(\rho \beta^{3}\right)$ の比で媒質補正した。地震本部 9)の $\rho, \beta$ は, $\mathrm{T} 1$ タイプのパラメータから剛性率を算出し, $\beta=3.8 \mathrm{~km} / \mathrm{s}$, $\rho=2.8 \mathrm{~g} / \mathrm{cm}^{3}$ と仮定した。媒質補正後の大正関東地震, 地震本部 9)の $\mathrm{T} 1, \mathrm{~T} 2$ タイプとも, 佐藤 ${ }^{36)}$ の $\mathrm{M}_{0}-\mathrm{A}$ 関係とほぼ合っている。この 結果は, 本研究の計算波が, 本郷での復元波や地震本部の計算波と ほぼ同レベルとなった結果と整合しており，予測式の M8 クラスの 相模卜ラフ沿いの地震への適用性をサポートするものである。

\section{（2）都心南部直下地震}

内閣府 7)の都心南部直下地震 $(\mathrm{Mw} 7.3, \mathrm{H}=43 \mathrm{~km})$ に対する統計的 グリーン関数法による計算波との比較を行った。Fig.21には, 用い た内閣府 7)の巨視的断層面(鉛直断層) と破壞開始点, 本研究のスラ ブ内地震に対する予測式(平均)に基づく周期 2 秒の $\mathrm{pSv}$ を示す。ご く一部の観測点で $100 \mathrm{~cm} / \mathrm{s}$ を超える程度である。周期 5 秒では, ほ ぼ $50 \mathrm{~cm} / \mathrm{s}$ 以下であった。Fig.22 には, TKY007(新宿)での本研究と 内閣府 7)の計算波の $\mathrm{pSv}$ の比較を示す。内閣府 7)の計算波は, 水平 2 成分の幾何平均值も示した。内閣府 7 の計算波は, 周期 3 秒以下 が有効である。内閣府 7), スラブ内地震の平均的な強震動生成域 の応力降下量の 1.2 倍の $62 \mathrm{MPa}$ を用いて計算を行っているが, 統 計的グリーン関数法であるため表面波は考慮されていない。本研究 の計算波が, 内閣府 7)の水平 2 成分の平均值よりやや大きい原因と して, 本研究の予測式では経験的に表面波が考慮されていることが 考えられる。予測式のデータセットに Mw7 以上のフィリピン海プ

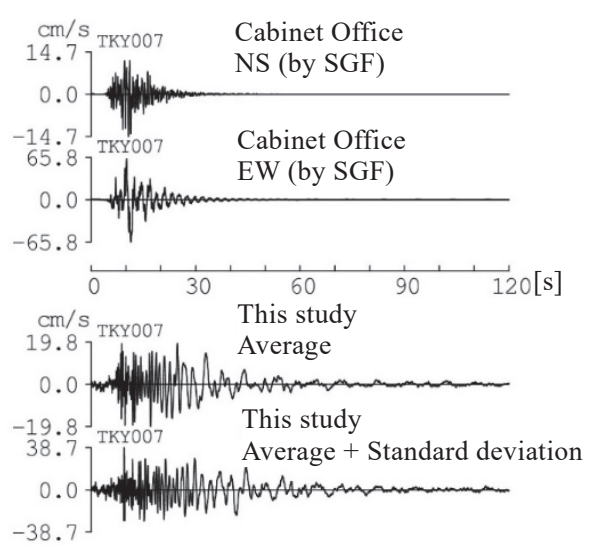

$\begin{array}{rrrrr}0 & 30 & 60 & 90 & 120[\mathrm{~s}] \\ \text { Fig.23 } & \text { Comparison of velocity } & \text { waveform }\end{array}$ predicted at TKY007 for the hypothetical south metropolitan earthquake in this study and by Cabinet Office ${ }^{7)}$

レートのスラブ内地震は含まれていないが, 1987 年千葉県東方沖地 震(Mw6.7)や 1855 年安政江戸地震 $(\mathrm{Mw}$ 7.1)の A が, 太平洋プレー トのスラブ内地震に対する梁さ依存の $\mathrm{M}_{0}-\mathrm{A}$ 関係 28$)$ とほぼ整合し

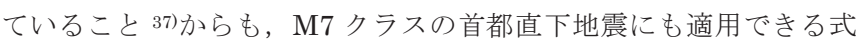
となっていると考えられる。Fig.23には, TKY007(新宿)での本研究 と内閣府 7)の計算波の周期 $0.1 \sim 10$ 秒の速度波形を示す。表面波の 影響も含まれている本研究の方がやや継続時間が長い。

\section{6. まとめ}

本研究では, 相模卜ラフ沿いの地震に対する長周期・長時間地震 動(水平成分)の予測のため, 国内の強震記録に基づき, 減衰定数 $5 \%$ の加速度応答スペクトル $\mathrm{S}_{\mathrm{A}}$ と群遅延時間の平均值・分散の予測式 を作成した。そして, 大正関東地震タイプ $(\mathrm{Mw} 7.9), \mathrm{M} 7$ クラスの想 定首都直下地震である都心南部直下地震 $(M w 7.3)$ に適用した。周期 1〜10 秒が主たる対象であるが, 周期 0.1〜 秒も同じ考え方で予測 式を作成している。本研究で得られた結論は以下の通りである。

1）相模トラフ沿いの地震については, $\mathrm{M}_{\mathrm{J}} \geqq 4$ の多数の記録をデー タセットに含め, 伝播経路・サイト特性の地域性を考慮した。そ の結果, 本研究で得られた $\mathrm{S}_{\mathrm{A}}$ の地盤増幅率は, 南海トラフ沿い の地震の予測式の地盤増幅率より小さく, 周期依存性も小さい 傾向が得られた。震源位置により表面波の励起特性が異なるこ とが反映されたものと考えられる。

2）震源近傍での $\mathrm{S}_{\mathrm{A}}$ の飽和の係数の推定に, 全国の地殼内地震の記 録も含め, 震源近傍も含む断層最短距離 $1.2 \sim 250 \mathrm{~km}$ での予測 を可能とした。震源近傍での $\mathrm{S}_{\mathrm{A}}$ の飽和は, 周期 1 秒以上で周期 が長いほど強くなり，周期 4〜10 秒でほぼ一定となる。

3） Mw3.7〜 8.2 の広い範囲のスケーリングを表現するため, NGAWEST2 のヒンジマグニチュードをパラメータとしたモデル化 を導入した結果, 観測の震源項が良くモデル化された。

4）プレート境界とスラブ内地震(深さ $75 \mathrm{~km}$ 以下)を区別し， $\mathrm{S}_{\mathrm{A}}$ の 予測式では，それぞれに対する震源深さ依存性を考慮した。 $\mathrm{S}_{\mathrm{A}}$ は深くなるほど長周期では小さくなり, 表面波の特徴がモデル 化されている。短周期では, 特にスラブ内地震で深くなるほど 大きくなる傾向が顕著で短周期レベルの特徵が反映されている。 5） 1 都 6 県の浅部・深部統合地盤構造モデルとモデル構築の際に 
用いられた K-NET, KiK-net 観測点直下の地盤モデルに基づき, 工学的基盤以浅の一次元的地盤増幅をはぎとり, 工学的基盤で の地盤増幅率を算出した。 $\mathrm{S}_{\mathrm{A}}$ の地表での地盤増幅率は, 周期 1 秒程度でも広い範囲で浅部地盤の増幅があったが, 工学的基盤 ではその影響が除かれた。

6) 工学的基盤での群遅延時間の平均值・標準偏差のサイト係数は, 工学的基盤から地表までの地盤の固有周期 $\mathrm{Ts}$ より長周期でも, Ts との相関がみられた。表面波が浅部地盤の影響も受け, 継続 時間が伸びていることを反映したものと考えられる。この結果 は, 工学的基盤以深の地下構造を用いた三次元有限差分法など では，このような影響を反映できないことを意味している。

7）プレート境界地震である大正関東地震に予測式を適用し, 本郷 での復元波や地震本部の三次元有限差分法の計算波とほぼ同レ ベルとなることを示した。これは, 大正関東地震や, 地震本部の 震源モデルが, 本研究のデータセットの多くを占める太平洋プ レートの地震の地震モーメントと短周期レベルの関係で説明で きることと整合する結果である。

8）スラブ内地震である都心南部直下地震に予測式を適用したとこ ろ, 内閣府の統計的グリーン関数法の計算波と比ベ, スペクト ルはやや大きく, 継続時間はやや長い波形が計算された。統計 的グリーン関数法では表面波が考慮されていないことを考慮す ると，整合する結果となっている。

\section{謝辞}

本研究は, 平成 $28 \sim 29$ 年度の国土交通省建築基準整備促進事業 による成果である。大川出博士には, 貴重なご意見を頂いた。1 都 6 県での浅部・深部統合地盤モデルと K-NET, KiK-net 観測点直下 での地盤モデルは, 防災科学技術研究所との共同研究協定に基づき, 先名重樹博士からご提供いただいたものである。また, 地震本部か ら関東地震の断層モデルのデータをご提供頂くとともに, 公開計算 波形を用いました。本研究では, 防災科学技術研究所の K-NET, KiK-net の記録, F-net の CMT 解, 気象庁の 87 型, 95 型震度計の 記録, 一元化震源情報, 建築学会が収集した各機関の 1987 年千葉 県東方沖地震の記録, 工学院大学の地震記録を用いました。東京大 学地震研究所が首都圈の自治体等の協力を得て運営している SKnet の強震記録も用いました。また, 内閣府が公開している震源モ デル，計算波形を用いました。なお，一部の図の作成には，GMT ${ }^{38)}$ を用いました。記して, 感謝致します。

\section{参考文献}

1) Nagano, M. et al.: Dynamic Characteristics of Super High-rise Residential Buildings in Kanto and Kansai Areas Based on Strong Motion Records During the 2011 off the Pacific Coast of Tohoku Earthquake, Journal of JAEE, pp. 65-79, 2012. 9 (in Japanese) 永野正行ほか 9 名: 2011 年東北地方太平洋沖地震時の強震記録に基づく 関東 - 関西地域に建つ超高層集合住宅の動特性, 日本地震工学会論文集, 第 12 巻, 第 4 号, pp. 65-79, 2012.9

2) Headquarters for Earthquake Research Promotion: On Update of Earthquake Probabilities by Long-Term Evaluation, from https:// www.jishin.go.jp/evaluation/long_term_evaluation/chousa_18feb_ kakuritsu_index/ (accessed 2018. 7. 16) (in Japanese) 地震本部：長期評価による地震発生確率值の更新について, 入手先, https://www.jishin.go.jp/evaluation/long_term_evaluation/chousa_18f eb_kakuritsu_index/ (参照 2018.7. 16)

3) Satoh, T. et al.: Revisions of Empirical Ground Motion Models and the Simulations of Long-period Strong Motions of the 2011 off the Pacific Coast of Tohoku Earthquake, Journal of JAEE, Vol. 14, No. 6, pp. 1-20, 2014. 12

4) Satoh, T. et al.: Prediction of Long-period Ground Motions for the Nankai Trough Mega-earthquakes Using Site-specific Empirical Relations, Journal of Structural and Construction Engineering (Transactions of AIJ), No. 695, pp. 37-46, 2014. 1 (in Japanese) 佐藤智美ほか 4 名：サイト固有の特性を反映した経験式に基づく南海卜 ラフ沿いの巨大地震に対する長周期地震動予測, 日本建築学会構造系論 文集, 第 695 号, pp. 37-46, 2014. 1

5) Nakagawa, H.: Development of Design Input Motion for High-rise Buildings Against Megathrust Earthquakes, Proc. the $12^{\text {th }}$ JapanChina Structural Engineering Workshop, 10pp. 2017. 9 (in Japanese) 中川博人：海溝型巨大地震に対する設計用長周期地震動の作成に関する 検討，第 12 回日中建築構造技術交流会論文集, 10pp., 2017. 9

6) Ministry of Land, Infrastructure, Transport and Tourism: On Countermeasures Against Long-period Ground Motions of Nankai Trough Mega-earthquakes for High-rise Buildings, from http:// www.mlit.go.jp/report/press/house05_hh_000620.html, (accessed 2018. 7. 16) (in Japanese)

国土交通省：超高層建築物等における南海トラフ沿いの巨大地震による 長周期地震動への対策について, 入手先, http://www.mlit.go.jp/report /press/house05_hh_000620.html (参照 2018. 7. 16)

7) Cabinet Office: Reports on Fault Model, Seismic Intensity and Tsunami Height of M7-class Tokyo Metropolitan Earthquakes and M8class Sagami Trough Earthquakes, from http://www.bousai.go.jp/ kaigirep/chuobou/senmon/shutochokkajishinmodel/ (accessed 2018. 7. 16) (in Japanese) 中央防災会議(事務局内閣府)首都直下モデル検討会：首都直下の M7 ク ラスの地震及び相模トラフ沿いの M8 クラスの地震等の震源断層モデル と震度分布・津波高等に関する報告書, 入手先, http:// www.bousai.go.jp/kaigirep/chuobou/senmon/shutochokkajishinmodel/ (参照 2018. 7. 16)

8) Yokota et al.: Estimation of Long-Period Ground Motion of the 1923 Great Kanto Earthquake, Journal of Structural and Construction Engineering (Transactions of AIJ), No. 401, pp. 35-45, 1989. 7 (in Japanese)

横田治彦ほか 3 名：1923 年関東地震のやや長周期地震動, 今村式 2 倍強 震計記録による推定, 日本建築学会構造系論文報告集, 第 401 号, pp. 3545, 1989. 7

9) Headquarters for Earthquake Research Promotion: Evaluation of Long-period Ground Motions, the 2016 Trial Version, Sagami Trough Mega-earthquakes, from https://www.jishin.go.jp/evaluation/seismic hazard_map/lpshm/16_choshuki/ (accessed 2018. 7. 16) (in Japanese) 地震本部：長周期地震動評価 2016 年試作版一相模卜ラフ巨大地震の検 討, 入手先, https://www. jishin.go.jp/evaluation/seismic_hazard_map /lpshm/16_choshuki/ (参照 2018. 7. 16)

10) Boore, D. M. et al.: NGA-West2 Equations for Predicting PGA, PGV, and 5\%-Damped PSA for Shallow Crustal Earthquakes, Earthquake Spectra, Vol. 30, No. 3, pp. 1057-1085, 2014. 8

11) Campbell, K. W. and Bozorgnia, Y.: NGA-West2 Ground Motion Model for the Average Horizontal Components of PGA, PGV, and 5\% Damped Linear Acceleration Response Spectra, Earthquake Spectra, Vol. 30, pp. 1087-1115, 2014. 8

12) Architectural Institute of Japan: Digitized Strong-motion Earthquake Records in Japan, Vol. 1, The off East Coast of Chiba Prefecture Earthquake, December 17, 1987, CD-ROM, 1992

13) Fukushima, Y. and Tanaka, T: Revision of Attenuation Relation of Peak Ground Accelerations Using New Dataset, Program and Abstracts, Seismological Society of Japan, p.116, 1992. 10 (in Japanese)

福島美光, 田中貞二: 新しいデータベースを用いた最大加速度の距離減 衰式の改訂, 地震学会講演予稿集, No. 2, 1992. 10

14) Satoh et al.: Prediction of Waveforms of Long-period Ground Motions 
for Hypothetical Earthquakes Using Empirical Regression Relations of Response Spectra and Phase Spectra, Journal of Structural and Construction Engineering (Transactions of AIJ), No. 649, pp. 521-530, 2010. 3 (in Japanese)

佐藤智美ほか 4 名：応答スペクトルと位相スペクトルの経験式に基づく 想定地震に対する長周期時刻歴波形の作成, 日本建築学会構造系論文集, 第 649 号, pp. 521-530, 2010. 3

15) Okada, Y. and Kasahara, K.: Earthquake of 1987, off Chiba, Central Japan and Possible Triggering of Eastern Tokyo Earthquake of 1988, Tectonophysics, Vol. 172, pp. 351-364, 1990. 2

16) Asano, K. et al.: Source Modeling and Strong Ground Motion Simulation of the off Miyagi Intraslab Earthquake of May 26, 2003, Zisin, Ser. 2, Vol. 57, pp. 171-185, 2004. 12 (in Japanese)

浅野公之ほか 2 名: 2003 年 5 月 26 日に宮城県沖で発生したスラブ内地 震の震源モデルと強震動シミュレーション, 地震 第 2 輯, 第 57 巻, pp. 171-185, 2004. 12

17) Suzuki, W. et al.: Rupture Process of the 2008 Iwate-Miyagi Nairiku, Japan, Earthquake Derived from Near-source Strong-motion Records, Bull. Seism. Soc. Am., Vol. 100, pp. 256-266, 2010. 2

18) Hikima, K.: Rupture Process of the April 11, 2011 Fukushima Hamadori Earthquake (Mj7.0) - Two Fault Planes Inferred from Strong Motion and Relocated Aftershocks -, Zisin, Ser. 2, Vol. 64, pp. 243-256, 2012. 8 (in Japanese)

引間和人： 2011 年 4 月 11 日福島県浜通りの地震 $(M j 7.0)$ の震源過程：強 震波形と再決定震源による 2 枚の断層面の推定, 地震 第 2 輯, 第 64 巻, pp. 243-256, 2012. 8

19) Kubo, H. et al.: Source-Rupture Process of the 2011 Ibaraki-oki, Japan, Earthquake (Mw 7.9) Estimated from the Joint Inversion of StrongMotion and GPS Data: Relationship with Seamount and Philippine Sea Plate, Geophys. Res. Lett., Vol. 40, pp. 3003-3007, 2013. 5

20) Asano, K. and Iwata T.: Source Rupture Processes of the Foreshock and Mainshock in the 2016 Kumamoto Earthquake Sequence Estimated from the Kinematic Waveform Inversion of Strong Motion Data, Earth Planets Space, Vol. 68: 147, doi:10.1186/s40623-016-05199, 2016. 8

21) Japan Meteorological Agency: Results of Source Inversion Analysis of Memorable Earthquakes in Japan, from http://www.data.jma.go.jp /svd/eqev/data/sourceprocess/ (accessed 2016. 10. 12) (in Japanese) 気象庁：国内で発生した顕著な地震の震源過程解析結果, 入手先, http://www.data.jma.go.jp/svd/eqev/data/sourceprocess/ （参照 2016. 10. 12)

22) Atkinson, G. M. and Silva, W.: Stochastic Modeling of California Ground Motions, Bull. Seism. Soc. Am., Vol. 90, pp. 255-274, 2000. 4

23) Yenier, E. and Atkinson G. M.: Regionally Adjustable Generic Groundmotion Prediction Equation Based on Equivalent Point-source Simulations: Application to Central and Eastern North America, Bull. Seism. Soc. Am., Vol. 105, pp. 1989-2009, 2015. 8

24) Satoh, T.: Stochastic Green's Functions Considering Surface Waves and Scattering Waves Using Strong Motion Records of Moderate-sized Intraplate Earthquakes Along the Sagami Trough, Journal of JAEE, Vol. 15, No. 1, pp. 116-135, 2015. 2 (in Japanese) 佐藤智美：相模卜ラフ沿いの中規模スラブ内地震記録に基づく表面波と 散乱波を考慮した統計的グリーン関数, 日本地震工学会論文集, 第 15 巻, 第 1 号, pp. 116-135, 2015. 2

25) Satoh, T and Tatsumi, Y.: Source, Path, and Site Effects for Crustal and Subduction Earthquakes Inferred from Strong Motion Records in Japan, Journal of Structural and Construction Engineering (Transactions of AIJ), No. 556, pp. 15-24, 2002. 6 (in Japanese) 佐藤智美，巽誉樹：全国の強震記録に基づく内陸地震と海溝性地震の震 源・伝播・サイト特性，日本建築学会構造系論文集，第 556 号, pp. 15-24, 2002. 6

26) Lawson, C. L. and Hanson, R. J.: Solving Least Squares Problems, Prentice-Hall, New York, 1974

27) Satoh, T.: Short-period Spectral Level, fmax and Attenuation of Outerrise, Intraslab and Interplate Earthquakes in the Tohoku District, Journal of Structural and Construction Engineering
(Transactions of AIJ), No. 689, pp. 1227-1236, 2013. 7 (in Japanese) 佐藤智美: 東北地方のアウターライズ地震, スラブ内地震, プレート境界 地震の短周期レベルと fmax 及び距離減衰特性, 日本建築学会構造系論 文集，第 689 号, pp. 1227-1236, 2013.7

28) Boore, D. M. et al.: NGA-West2 Equations for Predicting Response Spectral Accelerations for Shallow Crustal Earthquakes, PEER Report 2013/05, pp. 1-106, 2013. 5

29) Takano, K. and Uehara, M.: Current Status of Data Collection in the Seismic Kanto Strong Motion Network in Metropolitan Area, Technical Research Report, Earthquake Research Institute, the University of Tokyo, No. 20, pp. 1-10, 2014 (in Japanese) 鷹野澄, 上原美貴：首都圈強震動総合ネットワーク SK-netにおけるデー 夕収集の現状, 東京大学地震研究所技術研究報告, No. 20, pp. 1-10, 2014

30) Senna, S. et al.: Modeling of the Subsurface Structure from the Seismic Bedrock to the Ground Surface for a Broadband Strong Motion Evaluation, Journal of Disaster Research, Vol. 8, No. 5, pp. 889-903, 2013. 1

31) Headquarters for Earthquake Research Promotion: Modeling of the Subsurface Structure Subsurface Structure from the Seismic Bedrock to the Ground Surface in the Kanto Area, from https://www. jishin.go.jp/evaluation/seismic_hazard_map/underground_model/ integration_model_kanto/(accessed 2018. 7. 16) (in Japanese) 地震本部: 関東地方の浅部・深部統合地盤構造モデル, 入手先, https://www.jishin.go.jp/evaluation/seismic_hazard_map/ underground_model/integration_model_kanto/ (参照 2018. 7. 16)

32) Fujiwara et al.: Study on Application of Hazard Assessment of Longperiod Ground Motions, from https://www.jishin.go.jp/main/ chousakenkyuu/choshuki_shien/h27/h27_3-4.pdf (accessed 2018. 7. 15) (in Japanese)

藤原広行ほか 3 名：長周期地震動ハザード評価結果の活用の検討等，入 手先, https://www.jishin.go.jp/main/chousakenkyuu/choshuki_shien /h27/h27_3-4.pdf (参照 2018. 7.15)

33) Hatayama, K. et al.: Control Factors of Spatial Variation of Longperiod Strong Ground Motions in the Yufutsu Sedimentary Basin, Hokkaido, During the Mw 8.02003 Tokachi-oki, Japan, Earthquake, Bull. Seism. Soc. Am., Vol. 97, pp. 1308-1323, 2007. 9

34) Takemura, M.: Great Kanto Earthquake, Knowing Ground Shaking in Greater Tokyo Area. Kajima Institute Publishing, pp. 1-139, 2003. 5 (in Japanese)

武村雅之：関東大震災 大東京圈の摇れを知る, 鹿島出版会, pp. 1-139, 2003. 5

35) Satoh, T.: Estimation of Strong Motion Generation Areas and Strong Motions During the 1923 Kanto Earthquake Using Revised Stochastic Green's Function Method, Journal of Structural and Construction Engineering (Transactions of AIJ), No. 719, pp. 39-49, 2016. 1 (in Japanese)

佐藤智美：改良統計的グリーン関数法に基づく 1923 年関東地震の強震 動生成域と強震動の推定, 日本建築学会構造系論文集, 第 719 号, pp. 39-49, 2016. 1

36) Satoh, T.: Scaling Law of Short-period Source Spectra for Crustal Earthquakes in Japan Considering Style of Faulting of Dip-slip and Strike-slip, Journal of Structural and Construction Engineering (Transactions of AIJ), No. 651, pp. 923-932, 2010. 5 (in Japanese) 佐藤智美：逆断層と横ずれ断層の違いを考慮した日本の地殼内地震の短 周期レベルのスケーリング則, 日本建築学会構造系論文集, 第 651 号, pp 923-932, 2010. 5

37) Satoh, T.: Estimation of Broadband Source Model of the 1855 AnseiEdo Earthquake and the Strong Motions in the Tokyo Metropolitan and Regional Area Using the Empirical Green's Function Method, Journal of Structural and Construction Engineering (Transactions of AIJ), No. 727, pp. 1423-1433, 2016. 9 (in Japanese)

佐藤智美：経験的グリーン関数法に基づく 1855 年安政江戸地震の広带 域震源モデルと首都圈及び広域での強震動の推定，日本建築学会構造系 論文集，第 727 号, pp. 1423-1433, 2016. 9

38) Wessel, P. and Smith, W. H. F.: New, Improved Version of Generic Mapping Tools Released, EOS, AGU, 1998 


\title{
LONG-PERIOD AND LONG-DURATION GROUND MOTION PREDICTION EQUATIONS FOR EARTHQUAKES ALONG THE SAGAMI TROUGH BASED ON STRONG MOTION RECORDS
}

\author{
Toshimi SATOH*1, Hiroto NAKAGAWA ${ }^{* 2}$, Shin KOYAMA*3, \\ Toshiaki SATO ${ }^{* 4}$ and Masanobu TOHDO ${ }^{* 5}$
}

\author{
${ }^{* 1}$ Research Fellow, Ohsaki Research Institute, Dr.Eng. \\ ${ }^{* 2}$ Senior Research Engineer, Dept. of Structural Eng., Building Research Institute, Dr.Eng. \\ ${ }^{*}$ Research Managing Coordinator for Advanced Building Technology, National Institute for Land and Infrastructure Management, Dr.Eng. \\ ${ }^{* 4}$ Director, Ohsaki Research Institute, Dr.Eng. \\ ${ }^{*}$ Principal Researcher, Ohsaki Research Institute, Dr.Eng.
}

We develop long-period and long-duration ground motion prediction equations for earthquakes along the Sagami Trough based on strong motion records to utilize the equations to design input motions for high-rise buildings. Equations of 5\%damped acceleration response spectra $\mathrm{S}_{\mathrm{A}}$ and the average and variance of group delay time in the period range of 0.1 to $10 \mathrm{~s}$ are developed. Mw range of dataset is 3.7 to 8.2 . The fault distance range is 1.2 to $250 \mathrm{~km}$. The main features of the equations are as follows.

1) Since the strong motion records of big Sagami Trough earthquakes are rare, many records of earthquakes with $\mathrm{M}_{J} \geqq$ 4.0 along the Sagami Trough are added to records of big subduction-zone earthquakes $\left(\mathrm{M}_{J} \geqq 6.5\right)$ in whole Japan. The amplification factors for $\mathrm{S}_{\mathrm{A}}$ tend to be smaller than those for earthquakes along the Nankai Trough obtained by our previous paper. This result is the same result showed by 3-D FDM by Fujiwara et al..

2) Records of crustal earthquakes are used only to estimate a coefficient which represents the saturation effect to $S_{A}$ near fault regions because the upper depth of the Philippine Sea plate in south western part of Kanagawa prefecture is less than $10 \mathrm{~km}$. The saturation effect is stronger than that for earthquakes along the Nankai Trough obtained by our previous paper.

3) Magnitude coefficients for wide $\mathrm{Mw}$ range data are modeling well by introducing hinge magnitudes used in $\mathrm{S}_{\mathrm{A}}$ equations of NGA-WEST2.

4) Differences between interplate and intraplate earthquakes are modeling by using dummy valuables as fault depth dependency coefficients for $\mathrm{S}_{\mathrm{A}}$. The $\mathrm{S}_{\mathrm{A}}$ is larger as the depth is shallower in the long period range. This tendency reflects feature of surface waves.

5) Site coefficients of $\mathrm{S}_{\mathrm{A}}$ and group delay time obtained at the surface are converted to site coefficients at the engineering bedrock with an S-wave velocity of $400 \mathrm{~m} / \mathrm{s}$ based on 1-D wave propagation theory using shallow structures modeled by National Research Institute for Earth Science and Disaster Resilience (NIED). Even at a period of $1 \mathrm{~s}$ amplification factors for $S_{A}$ at the surface were affected by shallow structures in the wide region around the center of the Kanto plane but the effects are removed in amplification factors at the engineering bedrock.

6) Site coefficients of group delay time at the engineering bedrock become longer by shallow structures even in the periods longer than the predominant periods of shallow structures. This result means that 3-D FDM using the subsurface structure under the engineering bedrock cannot simulate these effects on duration by shallow structures.

The developed equations are applied to the 1923 Taisho Kanto (Mw7.9) type earthquake using fault models by the Headquarters for Earthquake Research Promotion (HERP). The long-period ground motion predicted near Hongo is consistent to the observed and restored record there. Predicted $\mathrm{S}_{\mathrm{A}}$ are comparable to those predicted by 3-D FDM by HERP. This result is reasonable because the scaling relation of spectral level of the 1923 Taisho Kanto earthquake and the source models by HERP almost agrees with the previous empirical relation for earthquakes along the Pacific plate which are major dataset of our equations. We also applied the developed equations to the hypothetical south Tokyo metropolitan earthquake (Mw7.3) using fault models by Cabinet Office. The predicted $\mathrm{S}_{\mathrm{A}}$ is a little larger and duration is a little longer than those predicted by stochastic Green's function method by Cabinet Office. This result is reasonable because surface waves are not considered in the stochastic Green's function method. 